This PDF is a selection from a published volume from the National Bureau of Economic Research

Volume Title: Tax Policy and the Economy, Volume 20

Volume Author/Editor: James M. Poterba, editor

Volume Publisher: The MIT Press

Volume ISBN: 0-262-16240-7

Volume URL: http://www.nber.org/books/pote06-1

Conference Date: September 15, 2005

Publication Date: September 2006

Title: Splitting Tax Refunds and Building Savings: An Empirical Test

Author: Sondra Beverly, Daniel Schneider, Peter Tufano

URL: http://www.nber.org/chapters/c0068 


\title{
Splitting Tax Refunds and Building Savings: An Empirical Test
}

\author{
Sondra Beverly, University of Kansas \\ Daniel Schneider, Harvard Business School \\ Peter Tufano, Harvard Business School, NBER, and D2D Fund
}

\section{Executive Summary}

Families are more likely to save if they can commit to savings before funds are in-hand (and subject to spending temptations). For low- and moderate-income U.S. families, an important savings opportunity arises annually, during income tax season. We study a group of lowincome individuals in Tulsa, Oklahoma, who were encouraged to save parts of their federal refunds at the time of tax filing. Those who agreed to save directed a portion of their refund to a savings account and arranged to have the rest sent to them in the form of a check. Eligible individuals could also open low-cost savings accounts. We document the demand for these services, the characteristics of those who sought to participate, the savings goals of those who participated, the immediate savings generated by the program, and the disposition of savings a few months after receipt. This pilot study suggests that there may be demand among low-income families for a refund-splitting program that supports emergency needs as well as asset building, especially if a basic savings product is available to all at the time of tax filing.

\section{Introduction}

Saving is hard work. A saver must defer gratification today for the sake of a better life tomorrow, much like a dieter, a recovering alcoholic, or an ex-smoker must resist the nearby chocolate cake, beer, or cigarette. In each case, removing the source of temptation is one prudent strategy. In this spirit, would-be savers often direct money to savings before they are tempted to spend it. Financial advisors tell people to "pay themselves first," 1 and this advice is embodied in a number of institutional programs. In the workplace, automatic investment plans 
enable workers to deduct monies from their paychecks to fund savings programs like 401(k) and 403(b) plans. Workers will sometimes force savings by increasing the amount of withholding on their W2 forms. Also in the workplace, the novel SMarT program, proposed by Thaler and Benartzi (2004), enables workers to precommit to save their raises. Outside the workplace, automatic investment plans, like those offered by mutual funds, allow investors to regularly sweep money from. transactional accounts into long-term investment accounts. Nearly all of the 500 largest mutual funds (defined by assets under management) allow investors to set up automatic monthly contributions.

All of these programs share a common trait: they tap into potential savings sources before a person has the opportunity to spend. For lowand moderate-income (LMI) ${ }^{2}$ U.S. families, annual federal and state tax refunds are an important source of savable funds. In 2001 (the most recent year for which data are available), LMI tax-filers received more than $\$ 78$ billion in total federal refund payments, including the earned income tax credit (EITC), the child tax credit (CTC), other refundable credits, and refunds from over-withholding (Internal Revenue Service, Statistics of Income 2001). ${ }^{3}$ This massive flow of funds, which takes place primarily during a few weeks in the early part of the tax season, represents a substantial portion of the inflows of an LMI family. With an average value of $\$ 1,415$ in 2001, a federal refund payment is often more than the amount of a low-income family's regular bi-weekly paycheck, perhaps hundreds of dollars more ${ }^{4}$ For a family with income of less than $\$ 30,000$ a year, the federal tax refund would likely be the single largest payment received all year. In addition to being large, tax refunds are perhaps the most savable of funds, out of reach for most of the year and hence beyond temptation.

Yet just as most workers cannot direct all of their salary into an automatic investment program, most refund recipients cannot direct all of their tax refunds to savings. In both cases, some funds are needed for current living expenses and perhaps to pay past-due bills. Ideally, a refund recipient could save part of her refund at the source, rather than receiving all of the money and then having to decide how much of it to spend and how much to save. This precommitment could be physical in nature (investing in a savings product with limited liquidity), mostly psychological in nature (mentally segregating funds for savings), or a combination of the two. However, neither the Internal Revenue Service (IRS) nor the financial service sector has moved quickly to enable LMI families to split their refunds and simultaneously precom- 
mit to savings. It is unclear whether this reluctance is motivated by a lack of facts (e.g., what fraction of families would use refund splitting if it were offered and how much money would be saved out of refunds), a lack of focus on low-income families by financial service firms, operational barriers to implementation, or perhaps other factors.

To gather some tentative empirical evidence about refund splitting, we entered into a collaborative research project in the spring of 2004..$^{5}$ As described in more detail below, for four weeks during the tax season, the team offered about 516 LMI filers at one of the nation's largest free tax preparation sites the ability to split their refunds into saving and spending components and, if needed, to open new savings accounts to house their new savings. A participant could also deposit his entire refund into a newly established account.

The collaborative research team included the Community Action Project of Tulsa County (CAPTC), Doorways to Dreams (D2D) Fund, the Bank of Oklahoma (BOk), the Annie E. Casey Foundation (AECF), and the coauthors of this study. The program was called Refunds to Assets (R2A), and the participants-whose adjusted gross incomes averaged $\$ 12,300$-were drawn from CAPTC's existing tax preparation sites, with staff from CAPTC working on-site to enroll clients in the program. D2D Fund oversaw the legal and administrative apparatus of splitting. BOk opened new accounts for participants who desired them. ${ }^{6} \mathrm{AECF}$ and D2D provided funding for the experiment. We, the academic research team, developed the research design, created and administered a series of surveys, and analyzed data from the experiment.

While our results are only suggestive, they support the intriguing notion that refund splitting might increase savings for low- and moderate-income families or help them better manage their spending. In short, we find that:

- Over 20 percent of refund recipients studied sought to participate in R2A by splitting their refunds, opening new savings accounts, or both. - Fifteen percent of refund recipients were able to participate in R2A. Of these 79 participants, 56 percent opened new accounts and split their refunds, 27 percent split their refunds and used existing accounts, and 17 percent chose not to split and instead deposited their entire refunds into new accounts.

- The average participant saved $\$ 606$ or about 47 percent of her refund. One-fourth of participants had existing savings. These participants sent 
an average of $\$ 924$ to savings; by their reports, this represented a 90 percent increase in savings. Three-fourths of participants reported no prior saving, and these participants sent an average of $\$ 479$ to savings.

- Participants had many savings goals, with the most common being general precautionary savings, car purchase or repair, and home purchase or repair. While we sometimes equate savings with long-term goals, many of the saving goals mentioned by these low-income families were short-term.

- About four months after receiving refunds, bank account level data shows that the average balance had dropped 83 percent. However, 78 percent of participants said that they were still saving or had met at least one of their savings goals, and a larger fraction of R2A participants were still saving a portion of the refund or had met a savings goal, when compared with a sample of refund recipients at a comparison site without access to the R2A service.

- Follow-up survey data show that an overwhelming majority of participants were pleased with the service, planned to use it again, would recommend it to their friends, and were willing to pay a nominal fee to split.

We are not alone in advancing the idea that tax refunds could constitute an important pool of potential savings. A refund-based savings plan has been tested in a study by a team of researchers associated with the Retirement Security Project. Working with H\&R Block, the researchers carried out an experiment in St. Louis in which they tested whether they could increase saving out of refunds by providing matchfunding to savers opening individual retirement accounts (IRAs). The preliminary results confirm evidence from other studies that matching programs can augment savings; ${ }^{7}$ in this case, IRA contributions increase with the level of match funding offered (Duflo, Gale, Liebman, Orszag, and Saez 2005). While our studies differ along some key dimensions, they independently provide suggestive evidence of the power of refund-based savings programs.

The remainder of this paper provides the motivation for this research project (Section 2), describes the experiment (Section 3), presents our findings regarding take-up and initial saving (Section 4), presents follow-up results related to saving outcomes and perceptions of the program (Section 5), and offers some tentative conclusions and suggestions for future research (Section 6). 


\section{Why Test Refund-Splitting for LMI Tax Filers?}

\subsection{Public Policy and Asset Building}

U.S. public policy enthusiastically encourages asset building through a host of programs, estimated by some to cost the government $\$ 335$ billion a year (Woo, Schweke, and Buchholz 2004). Calls for an ownership society underscore the belief that asset building can strengthen families and societies. By building financial assets, families can weather temporary income shocks, demonstrate credit-worthiness, purchase non-financial assets (like homes, durables, or education), earn income, and prepare for retirement. Evidence suggests that asset holding can lead to increased residential stability, higher levels of social and political engagement, and better life outcomes for children (Sherraden 1991, Page-Adams and Scanlon 2001).

Despite incentives to save and clear benefits from saving, Americans save little of their annual earnings and have little in financial assets. Data from the National Income and Products Accounts show that the personal saving rate in the United States is low by historical standards. In 2003, Americans saved just 1.4 percent of disposable income, sharply down from the 1950s through the 1990s when the saving rate was between 7 percent and 10 percent (Bureau of Economic Analysis 2004). ${ }^{8}$

In addition to having low saving rates, Americans generally have small stocks of assets. Haveman and Wolff (2001) have defined asset poverty as lacking enough assets to live at the poverty level for three months. Using this definition Caner and Wolff (2002) found that, in 1999, 40 percent of Americans did not have enough liquid assets to live at the poverty level for three months. In a later paper, Wolff and Caner (2004) find that asset poverty rates have been largely static from 1984 to 1999. More recent data from the Survey of Consumer Finances emphasizes the degree to which the poor have very low levels of assets; in 2001, 25 percent of households in the bottom income quintile had no financial assets at all (Aizcorbe, Kennickell, and Moore 2003).

Public policy supporting asset building largely targets those who have higher incomes and more assets. A recent report estimates that the bottom 60 percent of tax filers by income received less than 5 percent of the approximately $\$ 335$ billion that the federal government spent to encourage asset building through homeownership, retirement savings, small business development, and investing (Woo, Schweke, and Buchholz 2004). This bias is due in no small part to the provision 
of asset-building incentives through the income tax system, thereby delivering the highest benefits to those who pay the highest taxes. Reasonable people might disagree about where incentives for asset building should be concentrated on the basis of equity or macro-economic effect. However, in terms of strengthening families and civic values, adding some savings to those with the least probably has the largest marginal effect. Creating incentives to add $\$ 10,000$ in assets to a family with $\$ 1$ million in assets will surely have less impact than adding the same amount to a family with no assets.

\subsection{Refunds and Asset Building}

The current system encourages saving by reducing tax payments made by the well-to-do. These tax-payer based incentives are ineffective for low-income families who pay little tax, but the federal tax refund system is a potentially powerful way to facilitate asset building among LMI families. As discussed below, the federal tax system delivers sizeable refunds that can be practically and mentally separated from regular employment earnings used to support everyday expenses.

Many LMI households receive large tax refunds as a result of two federal tax credits: the fully refundable earned income tax credit $(\text { EITC })^{9}$ and the partially refundable child tax credit (CTC) ${ }^{10}$ The average refundable EITC benefit in 2001 was $\$ 1,840$ for the 10 million EITC claimants with adjusted gross income (AGI) of less than $\$ 15,000$, and $\$ 1,640$ for the 6.5 million families with AGI between $\$ 15,000$ and $\$ 30,000$ (Internal Revenue Service 2001). Data on the size of the refundable portion of the CTC are not available by income, but outlays on the refundable portion for all income groups were approximately $\$ 980 \mathrm{mil}-$ lion in 2001 and $\$ 5.8$ billion in 2003 (Carasso and Steuerle 2003). When all refund sources are considered (i.e., EITC, CTC, other refundable tax credits, and over-withholding), in 2001, more than 30 million filers with AGIs below $\$ 15,000$ received refunds worth $\$ 1,176$ on average, and 24.5 million filers with AGIs between $\$ 15,000$ and $\$ 30,000$ received $\$ 1,710$ on average. In the aggregate, these LMI families received more than $\$ 78$ billion in federal refunds (Internal Revenue Service 2001). Just as the tax system subsidizes the saving of wealthy Americans through preferential tax treatment for investment income, large tax refunds can help other Americans to save.

Not only does the tax system distribute substantial funds, but it does so in a way that - in part-facilitates savings. Neoclassical economic theory assumes that funds are fungible, but behavioral economists have documented the tendency for people to mentally group different 
monies into different pots. For example, one might write checks for day-to-day expenses from one account and for big ticket items from another. Or one might designate income from a primary job for living expenses and income from a secondary job as savings.

This notion of mental accounting relates to the behavioral hypothesis that people tend to view "irregular" income differently than wage and salary income, especially when the irregular in-flows are large (see, Thaler and Shefrin 1988). One specific prediction derived from behavioral economic theory is that people who receive sizeable tax refunds will consider saving at least some portion of their refunds or using refunds to make special purchases rather than financing routine expenses. Some evidence supports this hypothesis. Smeeding et al. (2000) found that 33 percent of a sample of 650 EITC recipients planned to save at least a portion of their tax refunds; 16 percent planned to purchase a car, repair a car, or make car payments; 13 percent planned to purchase furniture or household appliances; 10 percent planned to pay educational expenses; and 5 percent planned to purchase homes or move. Consumer Expenditure Survey data suggest that families often use tax refunds to purchase consumer durables, such as furniture and vehicles (Barrow and McGranahan 2000). Thaler (1994) recognized the savings opportunity presented by tax refunds and argued for an additional credit for filers directly depositing refunds into individual retirement accounts (IRAs).

Evidence regarding the use of tax refunds has also led volunteer and for-profit tax preparers to encourage refund recipients to save their refunds. Several free Volunteer Income Tax Assistance (VITA) tax preparation sites, locations that provide free income tax preparation services to low-income filers, have allowed tax filers to open savings accounts on-site and directly deposit their tax refunds into these accounts. ${ }^{11}$ These programs usually involve a partnership between a tax preparer (commercial or volunteer) and a financial institution. Table 4.1 lists some of these programs. The most complete evaluation to date of this type of service comes from a 2000 study of a program sponsored by Shorebank and the Center for Economic Progress. Over 400 Chicago tax filers were invited to open low-cost Shorebank savings accounts with their tax refunds, and about 20 percent did so. Twofifths of account-openers depleted their accounts very rapidly, but 14 percent maintained balances and perhaps added additional savings to the accounts (Beverly, Tescher, Romich, and Marzahl 2002).

In the private sector, some H\&R Block offices have piloted a program to encouraged clients to open savings accounts on-site as a means 


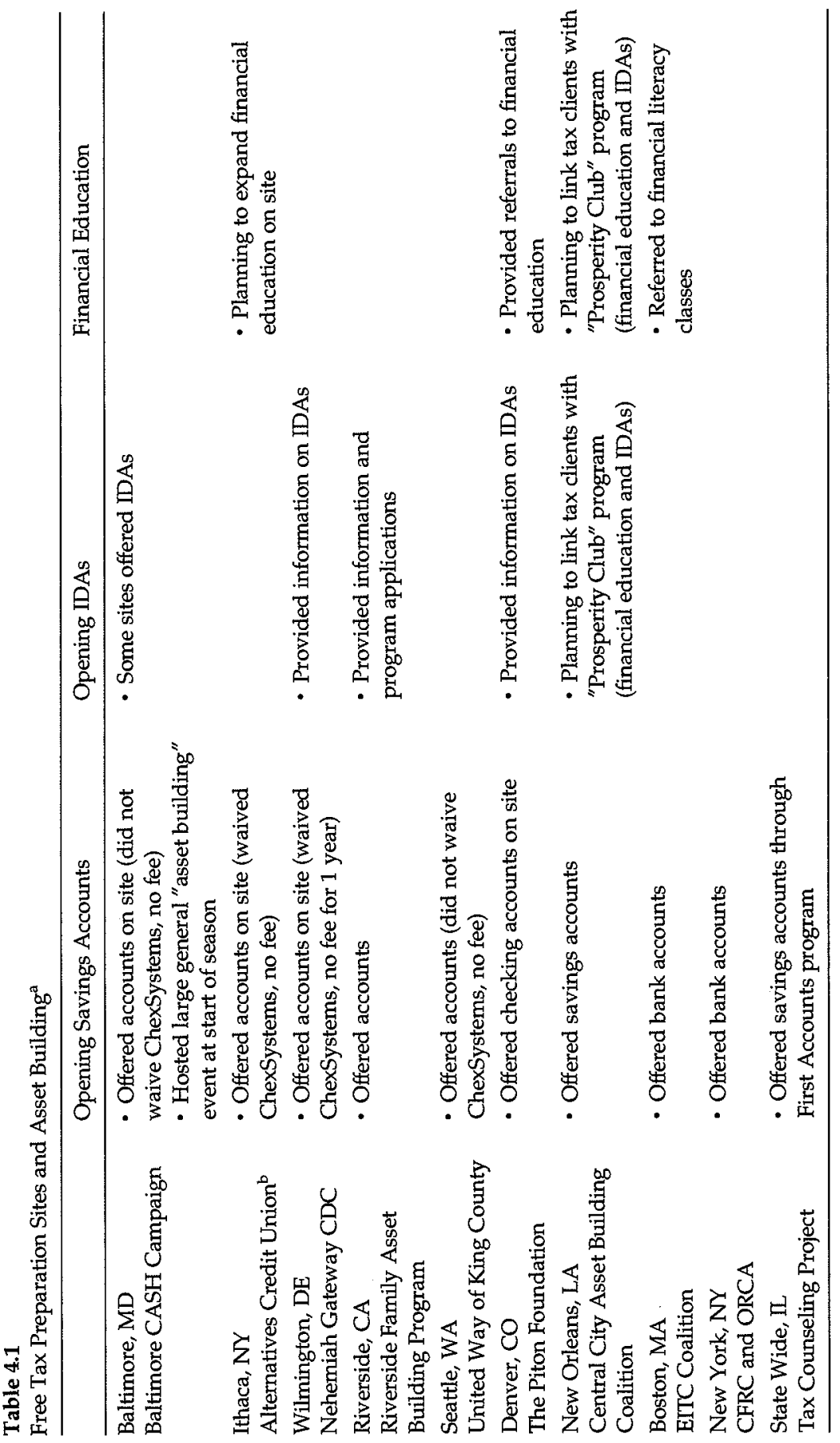




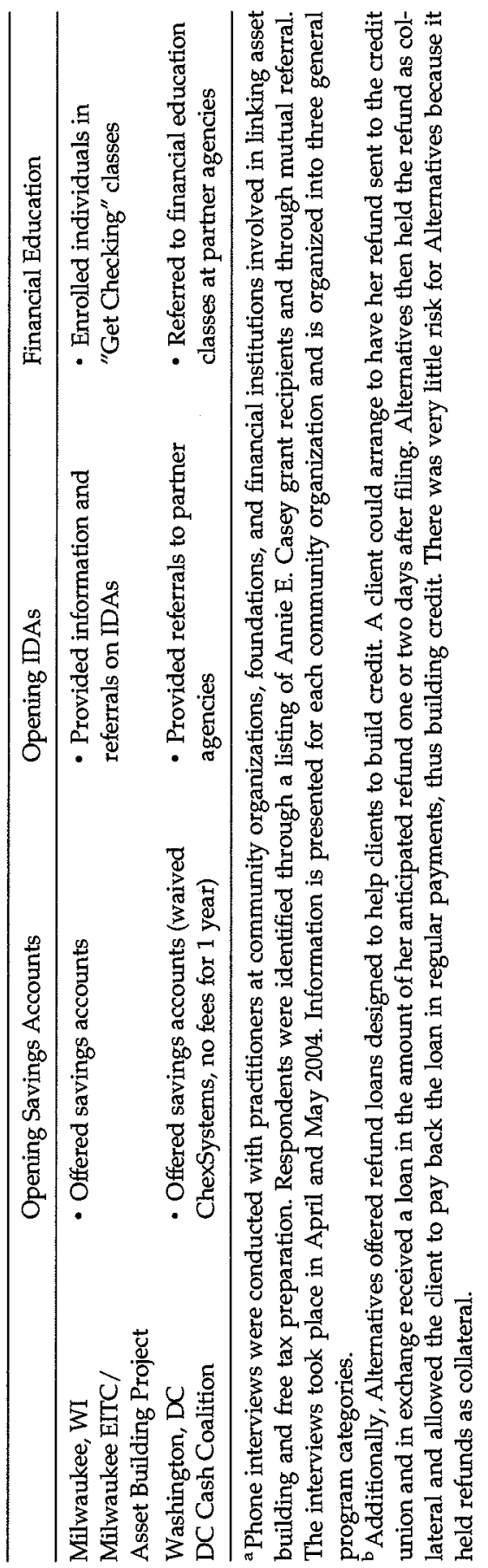


of accumulating emergency savings (Brookings Institution 2004). In the 2003 tax season, Block opened approximately 400 accounts with an average opening balance of $\$ 870$. Only 2 percent of Block clients at the offices offering the service opened accounts, but this take-up rate was depressed by rigorous account opening requirements based on a credit check (Tufano and Schneider 2004). Block also offered refund recipients on-site opening of IRAs. Over the three tax seasons from 2001 to 2004 , the company opened more than 440,000 Express IRA accounts. In 2004, the average balance on these accounts was $\$ 575$ (Tufano and Schneider 2004). As we mentioned earlier, a recent study conducted in St. Louis in conjunction with H\&R Block used the Express IRA product to test whether it would be possible to increase retirement savings at tax time (Duflo et al. 2005). Comparing this experiment with ours suggests some interesting hypotheses, which we will discuss later.

Behavioral economists posit that people often make irrational decisions about financial matters, due in large part to spending temptations (e.g., Shefrin and Thaler 1992; Thaler 1994, 2000). However, it is possible to deliberately modify incentives and constraints to avoid or overcome these temptations. Theory and empirical evidence suggests that helping people enforce self-discipline by precommiting money to savings is effective. For example, some people arrange to have retirement contributions automatically deducted from their paychecks. One novel program has increased savings by having workers precommit to save future raises. ${ }^{12}$ Another recent experiment in the Philippines allowed participants to make deposits into a restricted withdrawal account, not in exchange for higher interest rates, but merely as a device to commit to savings. Participants had significantly higher balances over time than members of a control (Ashraf, Karlan, and Yin 2006). Some people use mental or even physical accounting strategies to separate spending money from savings, and evidence suggests that these psychological and behavioral strategies help people resist the urge to withdraw savings (Beverly, Moore, and Schreiner 2003).

\subsection{Splitting Refunds and Building Assets}

If people undersave because they have trouble resisting spending temptations and if mental accounting helps people set aside money for savings, then refund splitting - physically separating funds designated for saving from funds designated for spending-may be a valuable tool to encourage saving. Currently, the IRS will send a refund to only one account, and most poor families cannot save all of their refund. Thus, whether the money is sent via a single paper check or directly 
deposited to a single account, the would-be saver must receive the entire refund, make a decision about saving, and then execute the saving plan while spending part of the money.

Any program that deposits all money in one place and requires recipients to save some leaves them open to spending temptations. Refund recipients may mentally earmark part of their refunds for savings, like a worker planning to save part of her paycheck. But unlike the worker who can use a variety of programs to precommit some earnings to savings, the refund recipient can only rely on her best intentions, saving once the refund check or deposit has been received. If it were possible to split the refund and send it to multiple destinations at the time of filing a tax return, then a family could mentally and physically separate saving and spending money and make saving automatic, thereby reducing the mental energy required to save. The intention to save would be further reinforced if the savings portion were directed to a savings-oriented financial product, especially one that restricts withdrawals to some degree (although this may discourage some from saving at all).

Some higher-income families have access to refund splitting. Vanguard, the second largest mutual fund company in the United States, allows investors to split their refunds among as many as four existing Vanguard accounts (including money market accounts with checkwriting privileges that can be used as transaction accounts). ${ }^{13}$ In 2004, Vanguard was the only company out of the ten largest banks and ten largest mutual funds with a formal splitting service, ${ }^{14}$ but some customers with some brokerage accounts in other firms may be able to have their brokers automatically split refunds across multiple investments. LMI families, however, are not likely customers of Vanguard (whose funds typically require a minimum investment of at least $\$ 3,000)^{15}$ nor of brokerage firms.

LMI families do have access to some refund splitting, albeit of a different form. Clients who take out refund anticipation loans (RALs) split their refunds, sending some to pay the tax preparer and receiving the remainder. RAL splitting does not build assets, however, but instead satisfies the need for very immediate spending. In addition, clients opting to purchase H\&R Block's Express IRA product at the time of tax preparation have the option of splitting their refunds, directing some to the newly opened IRA and receiving some as a direct deposit or as a paper check (Tufano and Schneider 2005). However, splitting tied explicitly to retirement savings may be less appealing to LMI families with shorter-term savings goals. 
On logical grounds, we hypothesized that a simple splitting program, with an option to open a new savings account, offered to LMI families at the time of tax filing would facilitate asset building among LMI families. We hypothesized that (1) some LMI refund recipients would choose to precommit part of their refunds; (2) splitting and precommitting would increase immediate savings; and (3) precommitting and splitting, by leveraging mental accounting, would perhaps even help people resist temptations to deviate from planned savings goals. Our collaborative research team was formed to gather evidence to support or reject these hypotheses.

\section{The 2003 Refunds to Assets Program}

During the 2003 tax season, the Community Action Project of Tulsa County (CAPTC) partnered with D2D Fund (D2D) to deliver the Refunds to Assets (R2A) program. CAPTC is a large community action agency based in Tulsa, Oklahoma, providing a variety of services, including housing assistance, child care, health services, emergency food and financial assistance, and individual development accounts (IDAs). ${ }^{16}$ CAPTC also provides free tax preparation to lowincome households. In 2002, volunteers completed about 14,300 federal returns. D2D Fund (www.d2dfund.org) is a non-profit organization dedicated to improving the delivery of financial services to low-income families and focused on the development and testing of innovative financial products and services. ${ }^{17}$

Clients at two of CAPTC's free tax preparation sites were invited to split their refunds, sending part to a savings account via direct deposit and arranging to receive the rest by mail as a check. We enlisted Bank of Oklahoma (BOk) as a partner so that participants could open new BOk savings accounts without leaving the tax preparation site. ${ }^{18}$ To be eligible, clients had to be at least 18 years old, have an expected federal tax refund, and agree to a set of legal authorizations. ${ }^{19}$ In addition, clients wishing to open a savings account with BOK had to pass a credit-check system used by the bank (ChexSystems) and have a valid driver's license or passport.

The pilot program was offered in two time periods during the tax season, during the first two weeks of February (the peak season for filing by those expecting refunds) and for two weeks in March. Recruitment and enrollment occurred on-site, while individuals were waiting to meet with tax preparers. ${ }^{20} \mathrm{CAPTC}$ staff and/or a member of our re- 
search team approached groups of CAPTC clients who were waiting to meet with tax preparers. They used a prepared script to describe R2A, emphasizing the program as a tool to split refunds and to encourage saving. Next, in one-on-one conversations, staff explained legal and research authorizations and collected preliminary information from those who did and did not want to participate. Individuals wanting to open BOk accounts completed a short form. Generally, at this point, potential participants began their tax preparation appointments while program staff opened accounts for those who requested them. Near the end of the tax preparation appointment, interested clients completed the R2A enrollment process and gave detailed written instructions for how their refunds should be divided. Although the script encouraged people to split their refunds, individuals who wanted to open new BOK accounts and deposit their entire refunds into these accounts were allowed to do so. Depending on filing date and on IRS processing times, the savings portion was directly deposited into the new BOk account or the participant's existing account about ten to fourteen days after the date of tax filing, and the participant received the remainder as a check shortly thereafter.

We collected data from three different groups:

1. Takers-137 individuals at the two CAPTC test sites who expected to receive refunds and who attempted to sign up for the program. These were subsequently divided into two subgroups: seventy-nine who ended up participating (participants), and fifty-eight who sought to participate but were unable to usually because they did not pass the BOk credit screen (foiled participants).

2. Decliners-Approximately 379 individuals at the two test sites who expected refunds but were not interested in participating in R2A.

3. Comparison group - fifty-three individuals at a CAPTC tax preparation site where R2A was not available who said that they would have participated in R2A had the program been offered. By design, this group had similar motives as the R2A participants, although they did not have the benefit of the program.

We collected several different sources of information (see table 4.2). Takers, decliners, and members of the comparison group completed a short written baseline survey during the enrollment process. For takers, this survey included questions about demographic characteristics, current savings, and planned refund uses. For decliners, this survey asked about demographic characteristics and reasons for 
Table 4.2

Response Rates per Data Source by Research Sample ${ }^{a}$

\begin{tabular}{|c|c|c|c|c|}
\hline Data Source & $\begin{array}{l}\text { Baseline } \\
\text { Survey }\end{array}$ & $\begin{array}{l}\text { Taxwise } \\
\text { Summary } \\
\text { Page }\end{array}$ & $\begin{array}{l}\text { Splitting } \\
\text { Instructions }\end{array}$ & $\begin{array}{l}\text { Follow-up } \\
\text { Survey }\end{array}$ \\
\hline Takers & $99 \%$ & $95 \%$ & NA & NA \\
\hline Participants ${ }^{b}$ & $100 \%$ & $99 \%$ & $83 \%$ & $55 \%$ \\
\hline Foiled & $97 \%$ & $89 \%$ & NA & NA \\
\hline Decliners & $63 \%$ & $65 \%$ & NA & NA \\
\hline Comparison group & $87 \%$ & NA & NA & $49 \%$ \\
\hline
\end{tabular}

a Information was collected from a number of sources for individuals approached on site by R2A program staff. All individuals were asked to complete a baseline survey, and information from a Taxwise summary sheet was collected for all decliners and takers. Information was also collected from the splitting instructions issued by those participants opting to split their refunds. Follow-up telephone surveys were conducted 3-5 months after refund receipt with participants and members of the comparison group. Finally, BOk provided account data for select participants. Data collected 2/9-2/21 and 3/15-3/ 26 of 2004 in Tulsa, Oklahoma, and 5/30-8/12 by telephone from Boston, Massachusetts. ${ }^{b}$ Calculated as the number of participants with data divided by the total number of participants signing research consent forms $(n=75)$. Four participants who did not complete research consent forms are excluded.

declining. For the comparison group, the baseline survey asked about demographic and financial characteristics as well as planned refund uses. ${ }^{21}$ Data on anticipated refund amount and adjusted gross income (AGI) were collected for takers and decliners from a summary information page generated by the Taxwise tax preparation software. Data on how R2A participants allocated their refunds between savings deposits and checks were taken from the refund-splitting instructions issued on site.

In addition to these baseline data, $\mathrm{R} 2 \mathrm{~A}$ participants and members of the comparison group were asked to complete a fifteen-minute phone survey three to five months after they received their refunds. Fifty-five percent of participants and 49 percent of comparison group members completed this follow-up survey. In total sixty-three respondents were successfully contacted, forty-one participants and twenty-two comparison group members. The survey included questions on actual refund use, satisfaction with R2A (for participants), and interest in similar services and products.

Before we discuss the research findings, we acknowledge some important research limitations: we studied a relatively small number of individuals in a single city under particular research conditions, 
and therefore we cannot be confident that our results are generalizable. However, given the paucity of research on this topic, even this small study may be useful in understanding the potential of refund splitting. One can think of our results as akin to a test market approach to research, as used by business marketers, where consumers are exposed to a product or service to gauge their likely reception.

We organize our discussion of the research findings in the next section around five topics:

1. Is there demand for refund splitting? What is the apparent take-up rate of refund splitting, and what are structural impediments to increasing take-up?

2. Who participated? What are the characteristics of participants?

3. Why did people choose to participate? What goals were participants trying to reach?

4. What was the immediate impact of the program on savings?

5. After a few months, did participants have better saving outcomes than the comparison group?

We defer a discussion of the sixth set of findings, regarding participants' thoughts about alternative splitting options, to the final section of the paper, where we discuss the implications of our research.

\section{Baseline Research Findings from the R2A Program}

\subsection{Take-Up and Participation Rates}

Table 4.3 summarizes information regarding the take-up rate for the R2A program at the two Tulsa sites. In brief, about 27 percent of refund recipients sought to participate in the $\mathrm{R} 2 \mathrm{~A}$ program (takers); 15 percent were able to participate (participants) and the remainder were "foiled" because they did not meet various eligibility standards, as described below. These figures represent our estimates of the demand for the R2A version of an asset-building strategy leveraging tax refunds. As we describe below, a more conservative estimate of the potential and actual demand for splitting alone would be 21 percent and 12 percent, respectively.

To determine potential demand, we divided the number of people who enrolled or attempted to enroll by the number of refund recipients approached by the staff. R2A program staff approached 556 individuals about enrolling in R2A during the four weeks the service was offered. Of these, we estimate that 516 anticipated a refund; this 
Table 4.3

Enrollment Outcomes ${ }^{\mathrm{a}}$

\begin{tabular}{lll}
\hline Outcome & Number & Percentage \\
\hline Take-up rate-program $^{\mathrm{b}}$ & 137 & 27 \\
Take-up rate-splitting $^{\mathrm{c}}$ & 110 & 21 \\
${\text { Take-up rate-new } \text { account }^{\mathrm{d}}}_{\text {Participation rate-program }^{\mathrm{e}}}$ & 98 & 19 \\
Participation rate-splitting $^{\mathrm{f}}$ & 79 & 15 \\
Participation rate-new account $^{\mathrm{g}}$ & 62 & 12 \\
Disqualification rate-program $^{\mathrm{h}}$ & 55 & 11 \\
Declined $^{\mathrm{i}}$ & 58 & 11 \\
\hline
\end{tabular}

a Individuals who were approached at the tax preparation site $(n=516)$ have been grouped into several categories: those who enrolled in the program, those who wanted to enroll in the program but could not, and those who declined to enroll. The first two of these groups are combined to form the group "Interested in Program." These individuals are referred to as "takers." The take-up rate, defined as the percentage of those approached on site expecting a refund who were interested in the program, is also presented. Take-up rates are estimated for the program as a whole (splitting and account opening), for splitting, and for account opening. Participation rate is defined as the percentage of those approached on site expecting a refund who successfully enrolled in the program. Participation rates are estimated for the program as a while, for splitting, and for account opening. Data collected $2 / 9-2 / 21$ and $3 / 15-3 / 26$ of 2004 in Tulsa, Oklahoma.

${ }^{\mathrm{b}}$ This group includes those who actually enrolled in the program (participants) and those who were interested in enrolling but were ineligible (foiled participants).

'Take-up rate for splitters is calculated by multiplying the percentage of participants splitting their refunds $(83 \%)$ by the number of foiled participants $(n=58)$, adding that number to the number of successful splitters $(n=62)$, and then dividing that total by the number of individuals approached who were expecting a refund $(n=512$ and excludes four participants who did not sign research consent forms).

dTake-up rate for new accounts is calculated following the same method as described above but for new accounts instead of splitters.

'This group includes individuals who successfully enrolled in the program.

f Participation rate for splitting is calculated as the number of splitters $(n=62)$ divided by the number of individuals approached expecting refunds $(n=512)$.

$\mathrm{g}$ Participation rate for new accounts is calculated as the number of individuals opening new accounts $(n=55)$ divided by the number of individuals approached expecting refunds $(n=512)$.

${ }^{\mathrm{h}}$ This group includes individuals who wanted to enroll in the program but were not eligible. See table 4.4 in this paper.

iThis group includes those who were approached by CAPTC staff about enrolling, but declined to participate. See table 4.6 in this paper for a more detailed explanation. 
Table 4.4

Enrollinent Outcomes for Takers ${ }^{a}$

\begin{tabular}{lll}
\hline Outcome & Number & $\begin{array}{l}\text { Percentage of } \\
\text { Takers }\end{array}$ \\
\hline Enrolled & 79 & 58 \\
Wanted to enroll $^{\mathrm{b}}$ & 58 & 42 \\
ChexSystems $^{\mathrm{b}}$ & 36 & 26 \\
Declined to wait $^{\mathrm{c}}$ & 6 & 4 \\
Refund too small in the end $^{\mathrm{d}}$ & 6 & 4 \\
Lacked proper identification $^{\mathrm{e}}$ & 4 & 3 \\
Underage $^{\mathrm{f}}$ & 3 & 2 \\
Did not have existing account number $^{\mathrm{g}}$ & 2 & 1 \\
Paper return error $^{\mathrm{h}}$ & 1 & 1 \\
\hline
\end{tabular}

a Some individuals who expressed interest in the program were unable to enroll. The percentage of all takers who either enrolled or were disqualified for specific reasons is shown in the table. Data collected 2/9-2/21 and 3/15-3/26 of 2004 in Tulsa, Oklahoma. b This category includes the individuals denied accounts, and thus participation in the program, by ChexSystems.

"Waiting time to complete enrollment in the program during very busy periods could be as long as 15-20 minutes; some clients declined to wait.

${ }^{d}$ Interested individuals began the enrollment process before learning the value of their refund; some individuals ultimately decided that their refunds were too small to make splitting worthwhile.

'In order to open an account, BOk required a valid driver's license issued at least 3 months prior to the account-opening date.

${ }^{\mathrm{f}}$ In order to open a non-custodial account, BOk required that the account-holder be at least 18 years old.

gIn order to split a refund between a check and an existing account, individuals needed to know the account number of their existing savings account.

${ }^{h}$ Nearly all individuals enrolling in the program filed electronically. Although it would have been possible to enroll in R2A even if paper-filing, one individual was mistakenly turned away for this reason.

number serves as the denominator for take-up and participation rates and equals the takers plus decliners. Of these 516, 137 wanted to enroll in the program, producing an estimated take-up rate of 27 percent.

Fifty-eight of the would-be enrollees (11 percent of the 516 eligible individuals) were turned away. Excluding these individuals from the numerator yields a participation rate of 15 percent, considerably above the 2 percent rate experienced by $H \& R$ Block, mentioned above. ${ }^{22}$ Table 4.4 gives reasons for disqualification. While some takers were foiled by lack of identification or age requirements, the most severe constraint was that individuals who wanted to open a BOk account had to pass BOk's ChexSystems standard. ChexSystems is a credit- 
screening device used by approximately 90 percent of bank branches nationwide (Quinn 2001). Subscribing banks use the product in two ways: as a reporting mechanism for current clients who have had problems using their accounts, often in the form of overdrafts or bounced checks, and as a data source to check the financial histories of potential new account-holders. Our team failed to ask BOk to waive ChexSystems requirements, and as a result, BOk's default rules were in place. The bank would not open a savings account for any individual with a ChexSystems record. ${ }^{23}$ This policy disqualified 26 percent of the individuals who wanted to enroll in the program.

Finally, we consider the actual demand for splitting alone. The R2A program allowed participants to split their refunds and to open new accounts. Among participants, 56 percent split to a new account, 27 percent split to an existing account, and 17 percent simply opened a new account and deposited all of their federal refund in it (even though this was not the intent of the program). If we exclude participants who did not use splitting services, then the potential and actual take-up rates are reduced to 21 percent and 12 percent, respectively.

All of the take-up and participation rates discussed thus far assume that participants split their refunds because they perceived value in dividing their refunds into portions for spending and saving and in being able to precommit to saving. However, it is possible that participants split for other reasons, and if this is the case, the take-up and participation rates above may overestimate the demand for splitting. First, participants may have split because they believed it was a prerequisite for account opening. The R2A outreach emphasized splitting, and some may have split simply to gain access to the BOK account. This interpretation has some support: in response to an open-ended question, 15 percent of the thirty-three splitters who completed the follow-up survey reported that opening an account was their primary reason for splitting. (Follow-up methods, response rate, and data are discussed in detail below.) On the other hand, the 17 percent who chose not to split their refunds recognized that splitting was not required.

Second, participants who opened new accounts and split their refunds may have been interested in both program features but may have been more interested in account opening. In the follow-up survey, more than 70 percent of those who split into new accounts $(n=22)$ reported that opening a new account was more important to them than splitting their refund. However, the fact these participants valued 
account opening over splitting does not necessarily mean that their interest in splitting was insignificant. In fact, in the follow-up survey, 94 percent of participants who said that account opening was more important than splitting said that they planned to split again next year.

Third, when asked why they split, a substantial share of splitters gave reasons that did not obviously and directly relate to splitting or physical/mental accounting. Fourteen percent of splitters said that they did so because of an interest in trying something new, 6 percent said they split to receive their refund faster, and 14 percent gave miscellaneous reasons (e.g., "because of the business" or "it just sounded like a good thing to do"). Another 18 percent of respondents gave a response that spoke broadly about saving without specifically referring to splitting (e.g., "to save for car insurance" or "just to have extra cash in case I ever run out"). These responses may indicate that people split because they believed splitting would help them save. However, if a participant believed that having a new account would help him save and that individual split simply to open an account, then this type of response could reveal perceived benefits of account-opening rather than perceived benefits of splitting. To the extent that R2A participants split simply to gain other benefits (most notably access to a savings account), even our estimates of 21 percent (potential take-up) and 12 percent (actual take-up) for splitting alone are biased upward.

\subsection{Characteristics of Subgroups}

Table 4.5 reports demographic characteristics of the various subgroups, including participants, foiled participants, takers, and decliners. Where possible, it also describes residents of Tulsa County. We begin by summarizing characteristics of participants. Participants had an average age of 35, were predominantly female, and were predominantly African-American or Caucasian. Their federal tax refunds averaged $\$ 1,381$. Over half of participants held full-time jobs, and more than three-quarters worked at least part-time. However, 12 percent of respondents were unemployed and currently looking for work, a figure that was twice the national unemployment rate The average adjusted gross income (AGI) was $\$ 12,297$. Overall, participants might be described as the working poor.

The last four columns of table 4.5 indicate whether participants are different from foiled participants and whether takers are different from decliners. ${ }^{24}$ Participants differ from foiled participants in three key 


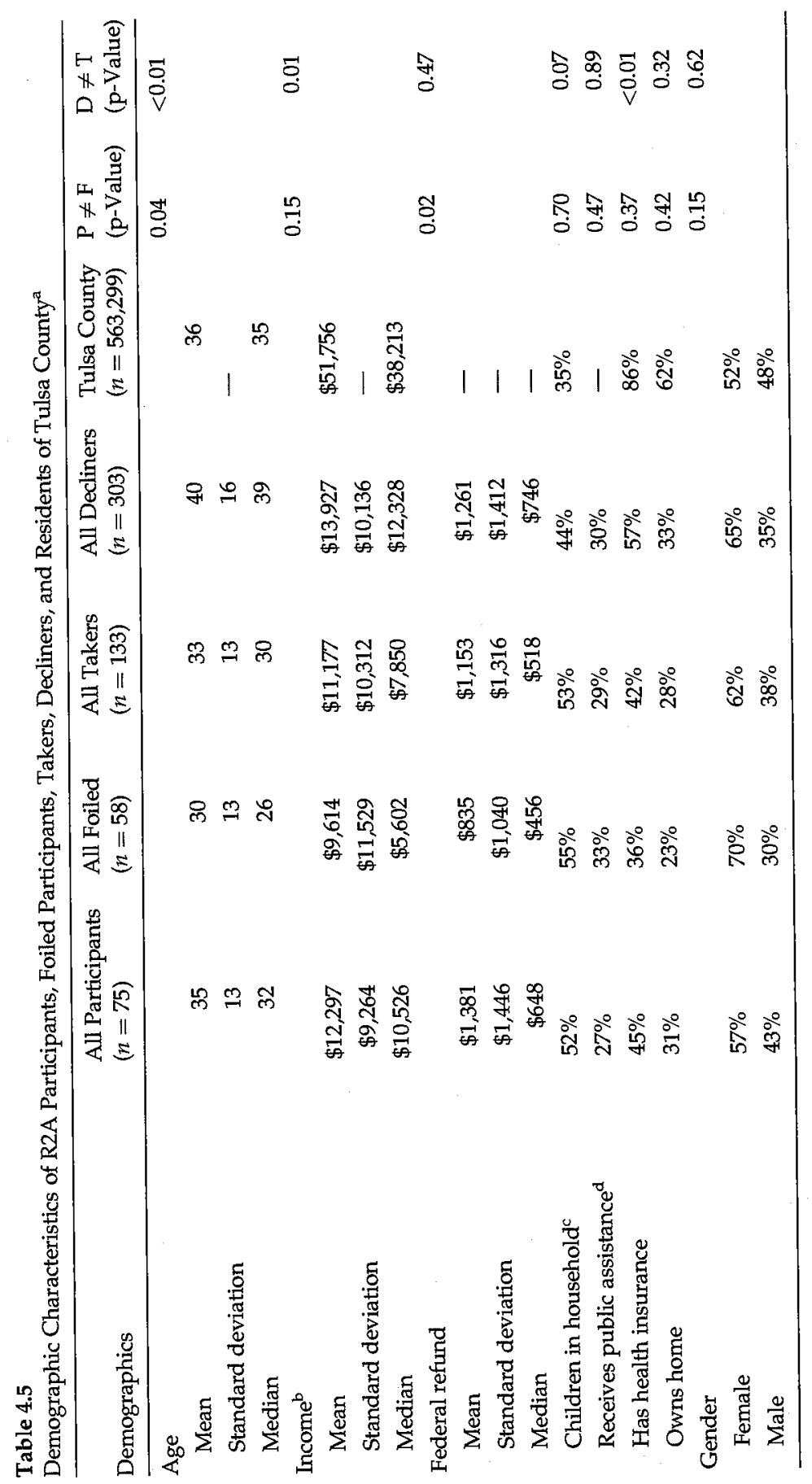




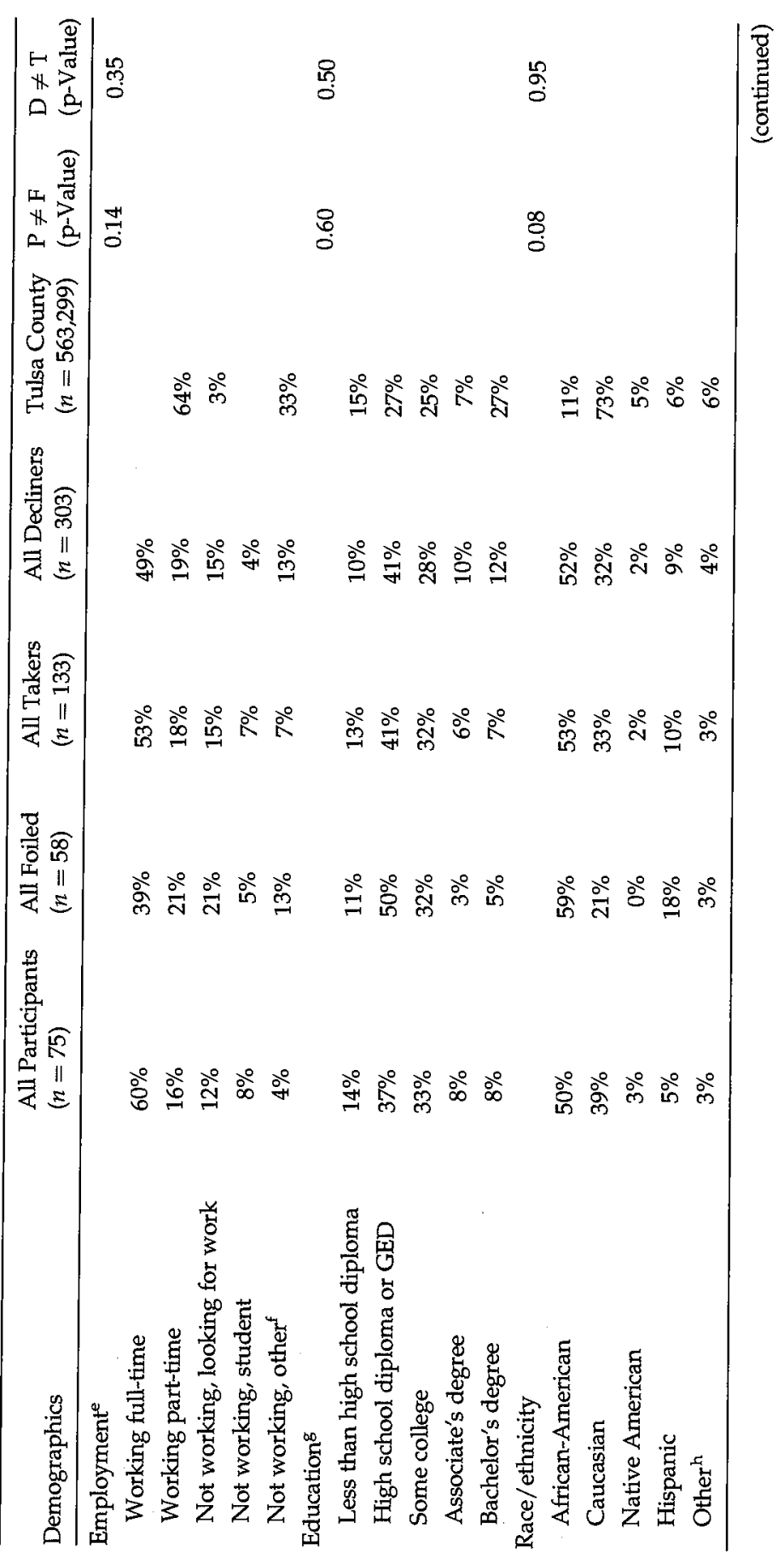




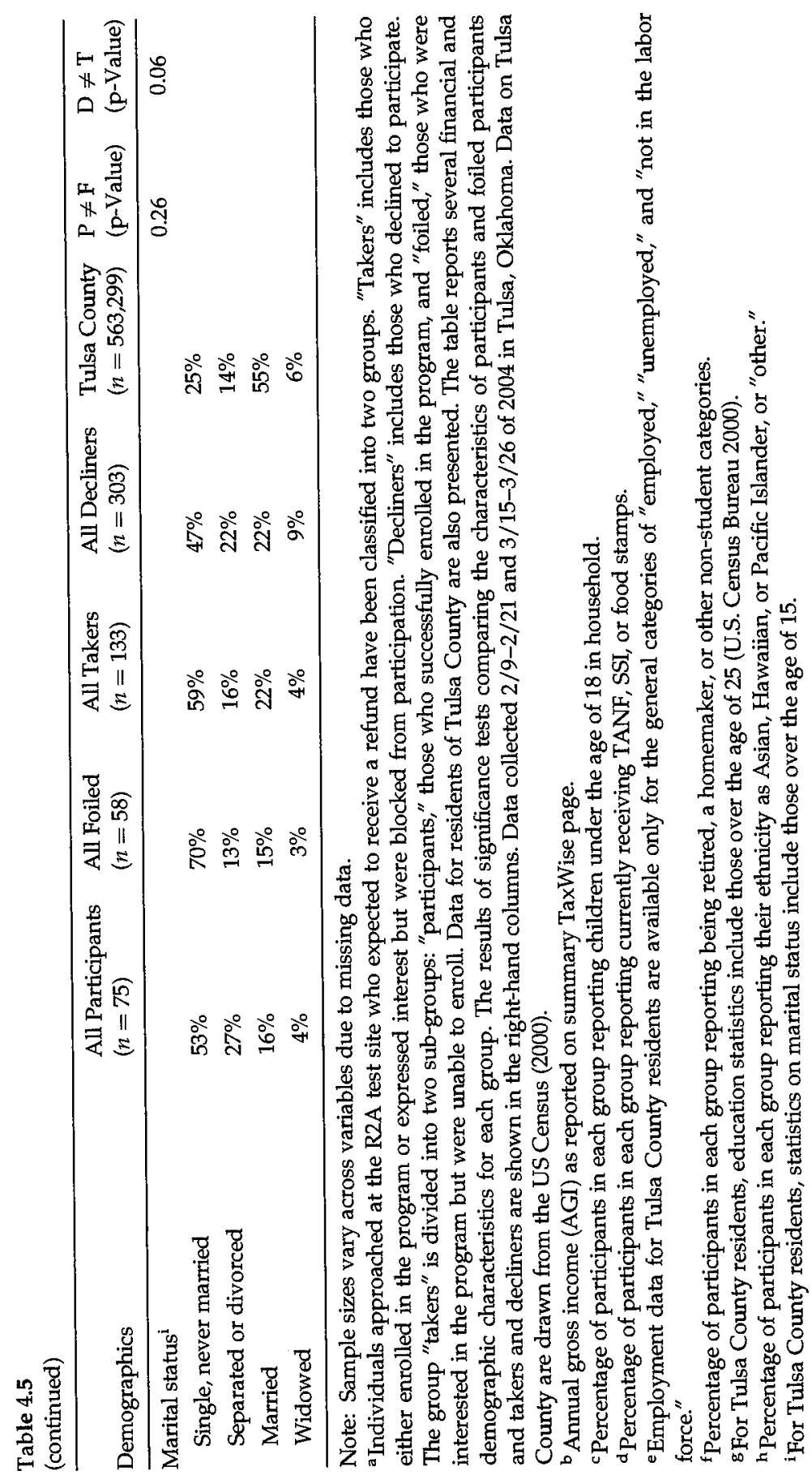


ways. Foiled participants were younger on average and had smaller average expected refunds than participants. They were also less likely to be white and more likely to be Hispanic and African-American.

Compared to decliners, takers (foiled and actual participants) tended to be younger and to have less income. They were more likely to have children, more likely to have never been married, and less likely to have health insurance. The mean AGI for takers was $\$ 11,177$, compared to $\$ 13,927$ for decliners. In short, those who wanted to participate were probably among the least financially stable households. This evidence-especially regarding income-is broadly consistent with the early evidence on IDAs, where one study has found that saving rates were highest among the lowest-income participants. ${ }^{25}$ If the ability to open a bank account was part of R2A's appeal (discussed in detail below), then this finding may reveal unmet demand for low-fee bank accounts by low-income working households.

\subsection{Stated Reasons for Declining and Participating}

In our baseline survey, we asked decliners why they were not interested in R2A. The question was closed-ended with an open-ended "other" option. Explanations for disinterest in R2A fall into two broad categories: "I don't need the service" or "I don't like the service" (see table 4.6). Ninety-four percent of respondents gave an answer that we classified in the first category. Forty-four percent of decliners said that they had already decided how to use their refund, and another 24 percent said that they planned to spend all of their refunds. Looking forward, we believe that some of those who said that they did not need the service might use it under other circumstances. Tulsa's economy was weak in early $2004,{ }^{26}$ and our conversations with tax filers revealed many cases of unemployment and unusual financial difficulties that prevented them from saving at all. In better economic times, some of these decliners might choose to split.

A much smaller percentage (9 percent) of decliners gave responses that we classified as "don't like the service." Some (4 percent) sought to have matching funds linked with the service or to deposit in an investment product dedicated to a specific purpose, ${ }^{27}$ and others (2 percent) expressed concerns about the security and reliability of the processing system used to split refunds. Both of these concerns could be addressed in the future by offering additional savings choices or by implementing the system more simply, as would happen if the IRS were to enable refund recipients to split their refunds. Finally, 2 
Table 4.6

Number and Percentage of Decliners Naming Reasons for Declining ${ }^{2}$

\begin{tabular}{|c|c|c|}
\hline & Number & Percentage \\
\hline "Don't need the service" & 285 & 94 \\
\hline Already decided how to use refund & 132 & 44 \\
\hline Plan to spend entire refund & 74 & 24 \\
\hline Refund too small to bother & 37 & 12 \\
\hline Don't need help saving or managing money & 28 & 9 \\
\hline Already have account ${ }^{\mathrm{b}}$ & 11 & 4 \\
\hline Began process but sent all to savings ${ }^{\mathrm{c}}$ & 3 & 1 \\
\hline "Don't like the service" & 26 & 9 \\
\hline Interested if there was a match or dedicated use $\mathrm{d}^{\mathrm{d}}$ & 12 & 4 \\
\hline Moving away & 7 & 2 \\
\hline Trust/privacy issues $f$ & 5 & 2 \\
\hline Other & 34 & 11 \\
\hline
\end{tabular}

andividuals who declined to participate in R2A, despite expecting a refund, gave a number of reasons for choosing not to enroll. These specific reasons have been grouped into the broad categories of "don't need the service" and "don't like the service." Individuals were permitted to give more than one response, so percentages sum to more than one $100 \%$. Data collected 2/9-2/21 and 3/15-3/26 of 2004 in Tulsa, Oklahoma.

${ }^{b}$ This group includes individuals who stated that they had an existing savings account with another bank and thus were not interested in opening a new savings account with BOk. Presumably, these individuals did not see a value in the splitting service alone.

cSeveral individuals began the enrollment process, but after talking with CAPTC staff, they decided to direct deposit their entire refunds into existing savings accounts.

${ }^{d}$ Individuals in this group stated that they would have been interested in the splitting program if additional incentives, such as a match or additional saving options, were available.

eA number of individuals said that they did not want to participate because they were moving away from the Tulsa area. Several of these individuals did not want to open a new bank account with $\mathrm{BOk}$, since they were leaving the area, and several noted that they were planning to close existing accounts and did not want to make additional deposits to those accounts. These responses essentially address portability concerns.

${ }^{f} \mathrm{~A}$ few individuals decided not to participate based on a distrust of banking institutions generally or a desire to limit the number of parties involved with the processing of their refund to ensure their privacy. 
percent said that they did not want to participate because they were moving away. Therefore, they did not want to open new accounts or make additional deposits into soon-to-be-closed accounts.

In our follow-up survey, we asked participants why they chose to participate in R2A. As noted above, the most common reason respondents gave for splitting their refunds was to separate their refunds into spending and saving portions (27 percent). Participants also reported that they chose to split in order to save (18 percent), to avoid spending all of the refund (12 percent), to try something new (15 percent), and finally because they wanted to open an account (15 percent). Respondents who opened new accounts listed a desire to save (29 percent) as the leading reason for account opening. One-quarter of respondents reported that they had wanted a savings account, and 16 percent said that they opened an account simply because they were offered one. The BOk brand had some currency among this population, with 19 percent citing it as the primary reason they opened an account, the same share that chose to open an account because of the terms offered. When all account openers were asked about these specific account features, the largest share of respondents reported that the convenience of opening an account on site was most important to them (44 percent). The waiver of minimum balance requirements ( 13 percent) and fees (13 percent), as well as the opportunity to earn interest on savings (13 percent) also attracted many participants. Fewer participants were drawn in by the faster processing time for refunds deposited into bank accounts ( 9 percent) or using their tax refund as the opening balance ( 6 percent).

The motives of participants may also be understood through the lens of their planned refund uses and, more concretely, their immediate savings goals. In the baseline survey, we asked participants if they planned to spend, save, or repay debt with their refunds and then used open-ended questions to probe for more specific plans in each of these categories. We grouped these open-ended comments into various categories. For example, people could report that they planned to use refunds to pay rent (spending), to make mortgage payments (debt repayment), or to save for a future home (savings). We classified all three as housing-related refund uses, but only the last would be classified as a savings goal.

The first three columns of table 4.7 summarize planned refund uses for participants. Savings uses made up the largest single grouping of planned uses. Eighty-one percent of participants planned to save part 
Table 4.7

Percentage of Participants and Comparison Group Members Reporting Types of Planned Refund Use by Method of Use ${ }^{a}$

\begin{tabular}{|c|c|c|c|c|c|c|}
\hline & \multicolumn{3}{|c|}{ Participants $(n=69)$} & \multicolumn{3}{|c|}{ Comparison $(n=36)$} \\
\hline & Save & Spend & Repay & Save & Spend & Repay \\
\hline Any & $81 \%$ & $57 \%$ & $45 \%$ & $56 \%$ & $58 \%$ & $56 \%$ \\
\hline General saving & $16 \%$ & $0 \%$ & $0 \%$ & $0 \%$ & $0 \%$ & $0 \%$ \\
\hline Emergency saving & $13 \%$ & $0 \%$ & $0 \%$ & $6 \%$ & $0 \%$ & $0 \%$ \\
\hline Housing ${ }^{\mathrm{b}}$ & $15 \%$ & $9 \%$ & $1 \%$ & $13 \%$ & $6 \%$ & $0 \%$ \\
\hline $\mathrm{Car}^{\mathrm{c}}$ & $13 \%$ & $12 \%$ & $4 \%$ & $8 \%$ & $11 \%$ & $6 \%$ \\
\hline Education $^{\mathrm{d}}$ & $4 \%$ & $1 \%$ & $1 \%$ & $0 \%$ & $8 \%$ & $0 \%$ \\
\hline Business & $1 \%$ & $1 \%$ & $0 \%$ & $0 \%$ & $0 \%$ & $0 \%$ \\
\hline Retirement & $5 \%$ & $0 \%$ & $0 \%$ & $2 \%$ & $0 \%$ & $0 \%$ \\
\hline Children & $4 \%$ & $4 \%$ & $1 \%$ & $0 \%$ & $2 \%$ & $0 \%$ \\
\hline Special events ${ }^{e}$ & $4 \%$ & $1 \%$ & $0 \%$ & $6 \%$ & $0 \%$ & $0 \%$ \\
\hline Bills & $3 \%$ & $19 \%$ & $13 \%$ & $0 \%$ & $2 \%$ & $2 \%$ \\
\hline Medical & $1 \%$ & $1 \%$ & $3 \%$ & $0 \%$ & $0 \%$ & $9 \%$ \\
\hline Durables & $1 \%$ & $4 \%$ & $1 \%$ & $0 \%$ & $4 \%$ & $2 \%$ \\
\hline Moving expenses & $1 \%$ & $4 \%$ & $0 \%$ & $0 \%$ & $2 \%$ & $0 \%$ \\
\hline Living expenses ${ }^{\mathrm{f}}$ & $1 \%$ & $0 \%$ & $1 \%$ & $0 \%$ & $8 \%$ & $0 \%$ \\
\hline Miscellaneous & $7 \%$ & $1 \%$ & $3 \%$ & $0 \%$ & $2 \%$ & $4 \%$ \\
\hline Credit cards & $0 \%$ & $0 \%$ & $12 \%$ & $0 \%$ & $0 \%$ & $13 \%$ \\
\hline Utilities & $0 \%$ & $0 \%$ & $5 \%$ & $0 \%$ & $0 \%$ & $2 \%$ \\
\hline Loans & $0 \%$ & $0 \%$ & $3 \%$ & $0 \%$ & $0 \%$ & $2 \%$ \\
\hline Clothes & $0 \%$ & $7 \%$ & $0 \%$ & $0 \%$ & $0 \%$ & $0 \%$ \\
\hline Taxes & $0 \%$ & $0 \%$ & $0 \%$ & $0 \%$ & $0 \%$ & $6 \%$ \\
\hline Family transfers ${ }^{g}$ & $0 \%$ & $0 \%$ & $0 \%$ & $0 \%$ & $0 \%$ & $2 \%$ \\
\hline
\end{tabular}

a Participants and comparison group members reported a wide variety of planned refund uses. Respondents were asked if they planned to save part of their refund, spend part, and/or repay debt with part. The first row of the table shows the percentage of participants naming any planned refund uses in each of these broad categories. The percentages sum to more than $100 \%$ because participants could name multiple methods of use. Respondents also provided information on specific planned uses. The percentage of participants reporting each specific refund use by method is presented in rows 2 to 22 . Data collected 2/9-2/21 and 3/15-3/26 of 2004 in Tulsa, Oklahoma.

${ }^{b}$ Includes home purchase, home improvement, and rental housing uses.

'Includes car purchase, car repair, and other car-related uses (such as insurance).

dIncludes tuition and school supplies.

'Includes trips, gifts, and events such as weddings and funerals.

f Includes food purchases and other general household expenses.

gIncludes financial transactions between family members, including repaying of debt and making loans and gifts. 
of their refund, with 57 percent and 45 percent planning spending or debt repayment, respectively. As expected in a splitting program, participants planned multiple and varied uses for their refunds. Specifically, 41 percent of participants planned both a savings and a spending use; 32 percent planned a savings and a debt-repayment use; 17 percent planned a spending and a debt-repayment use; and 16 percent planned a savings, a spending, and a debt-repayment use (results not shown).

Because R2A aimed to encourage saving, we paid special attention to planned savings uses. The most common savings goal, named by 16 percent of participants, was "general" saving, including responses like "to build savings," or "just to have money." The next most common savings goals were saving for housing-related uses (15 percent, mostly for home purchase but also for home improvement), saving for emergencies (13 percent), and vehicle-related saving (13 percent, mostly car purchase and car repair). Retirement saving, a major focus of public policy, was mentioned by only 5 percent of participants. This may indicate that participants have more immediate savings needs; however, these same people might become interested in saving for retirement in future years. It is also possible that the product choice available in R2A-a simple savings account best suited to short-term savings rather than an IRA-did not appeal to filers planning to save for retirement.

\subsection{Initial Savings Amounts}

The initial savings that the R2A program generated can be benchmarked in three ways: in dollars per participant, as a percentage of refund amount, and as a fraction of pre-program savings. By any of these measures, R2A participants initially saved a substantial amount. See table 4.8 for data on initial deposits to savings. The mean (median) participant directed $\$ 606(\$ 203)$ into savings. This represented 47 percent (39 percent) of her refund. Combining baseline survey data on existing savings with data on amount of refund sent to savings shows the immediate effect of R2A on household savings. On a per capita basis, savings increased from $\$ 276$ before the receipt of refunds to $\$ 863$ after refund receipt. This change represented a $\$ 587$ per capita increase, 213 percent growth. ${ }^{28}$

Participants contain two interesting subgroups: one subgroup reporting some savings before the program and a second reporting no prior savings. Individuals with existing savings had larger refunds and 
Table 4.8

Aggregate Initial Saving out of Refund ${ }^{a}$

\begin{tabular}{|c|c|c|c|}
\hline & $\begin{array}{l}\text { All } \\
\text { Participants } \\
(n=75)\end{array}$ & $\begin{array}{l}\text { All } \\
\text { Splitters } \\
(n=62)\end{array}$ & $\begin{array}{l}\text { All New } \\
\text { Account } \\
(n=58)\end{array}$ \\
\hline \multicolumn{4}{|l|}{ Amount sent to savings } \\
\hline Mean & $\$ 606$ & $\$ 579$ & $\$ 490$ \\
\hline Standard deviation & $\$ 905$ & $\$ 883$ & $\$ 1,011$ \\
\hline Median & $\$ 203$ & $\$ 200$ & $\$ 174$ \\
\hline Minimum & $\$ 3$ & $\$ 15$ & $\$ 3$ \\
\hline Maximum & $\$ 4,000$ & $\$ 4,000$ & $\$ 4,000$ \\
\hline \multicolumn{4}{|c|}{$\begin{array}{l}\text { Amount sent to savings as a } \\
\text { percentage of anticipated refund }\end{array}$} \\
\hline Mean $^{\mathrm{b}}$ & $47 \%$ & $38 \%$ & $46 \%$ \\
\hline Standard deviation & $33 \%$ & $27 \%$ & $36 \%$ \\
\hline Median & $39 \%$ & $33 \%$ & $35 \%$ \\
\hline Minimum & $2 \%$ & $2 \%$ & $2 \%$ \\
\hline Maximum & $100 \%$ & $98 \%$ & $100 \%$ \\
\hline
\end{tabular}

${ }^{a}$ Data on total and individual measures of amount of refund sent to savings are presented below for all participants, all participants who split their refunds, and all participants who opened new accounts. Data collected $2 / 9-2 / 21$ and $3 / 15-3 / 26$ of 2004 in Tulsa, Oklahoma.

${ }^{b}$ Calculated as the mean of individual savings as a percentage of refund.

directed a larger portion (mean $=60$ percent) of their refunds to savings accounts. In contrast, greenfield savers-individuals without existing savings-received smaller refunds and directed less to savings (mean $=42$ percent). With smaller refunds and smaller shares directed to savings, greenfield savers sent an average of $\$ 479$ to savings versus $\$ 924$ by existing savers. These values represent an infinite and a 90 percent increase in savings for the two groups, respectively. In both cases, the increase in savings was large, at least initially.

\section{Follow-Up Results}

In this section, we use available data to examine whether R2A seemed to help participants save part of their refunds and meet specific savings goals. As noted above, we conducted a follow-up telephone interview of R2A participants and comparison group members three to five months after refund receipt. Forty-one (55 percent) of the seventy-five participants, and twenty-two (42 percent) of the fifty-three comparison 
group members completed this interview. ${ }^{29}$ To assess comparability between these samples, panel A of table 4.9 shows demographic characteristics of the baseline and follow-up samples, for participants and comparison group members. Panel B of table 4.9 shows planned refund uses for these four samples.

The follow-up participant sample is quite similar demographically to the baseline participant sample. The most notable differences are related to home ownership, employment, and race. Members of the follow-up sample were less likely than those in the baseline sample to own homes ( 25 percent versus 31 percent). They were more likely to work full-time (67 percent versus 60 percent) and to be white ( 44 percent versus 39 percent). Planned refund uses are also quite similar for these two groups, with one exception: the follow-up sample was less likely to name a planned spending use than the baseline sample ( 49 percent versus 57 percent).

Differences between the follow-up sample of participants and the follow-up comparison sample are more pronounced. Comparison group members were much more likely to own homes (56 percent versus 25 percent) and to be female ( 88 percent versus 59 percent). Comparison group members also had higher incomes. All of these differences are statistically significant. Other differences approach statistical significance: comparison group members were more likely to be white (65 percent versus 44 percent), they had less education, and they had smaller anticipated refunds. ${ }^{30}$ (Actual refund amounts were quite similar for the two groups.) With the exception of education, the comparison sample appears to be more advantaged than the participant sample.

If one assumes that the advantaged sample is more likely to save part of their refunds and meet specific savings goals, then demographic characteristics suggest that comparisons between the followup participant and comparison samples represent a conservative test of the impact of R2A. Data on planned refund use complicate matters, however. The follow-up comparison sample was less likely than the follow-up participant sample to name a planned savings use (63 percent versus 82 percent) and more likely to name spending and debt repayment uses. Differences in savings and repayment goals approach statistical significance. If these observed differences are not due to chance, they may represent individual differences not captured by the demographic variables. Or they may suggest that R2A had an immediate impact on planned refund uses. The latter is consistent with the fact 
Table 4.9

Demographic Characteristics and Planned Refund Uses for Participants and Comparison Group Members in the Baseline and Follow-up Samples ${ }^{a}$

\begin{tabular}{|c|c|c|c|c|c|}
\hline & \multicolumn{2}{|c|}{ Participants } & \multicolumn{2}{|l|}{ Comparison } & \multirow{2}{*}{$\begin{array}{l}\mathrm{PF} \neq \mathrm{CF} \\
\mathrm{p}-\text { Value }\end{array}$} \\
\hline & Baseline & Follow-up & Follow-up & Baseline & \\
\hline \multicolumn{6}{|c|}{$\overline{\text { Panel A: demographic characteristics }}$} \\
\hline \multicolumn{6}{|c|}{ Age $^{\mathrm{b}}$} \\
\hline Mean & 35 & 36 & 37 & No data & 0.62 \\
\hline Standard deviation & 13 & 12 & 17 & No data & \\
\hline Median & 32 & 34 & 41 & No data & \\
\hline \multicolumn{6}{|l|}{ Income ranges ${ }^{c}$} \\
\hline$\$ 0-\$ 10,000$ & $50 \%$ & $51 \%$ & $15 \%$ & $30 \%$ & 0.02 \\
\hline$\$ 10,001-\$ 20,000$ & $24 \%$ & $22 \%$ & $50 \%$ & $32 \%$ & \\
\hline$\$ 20,001+$ & $26 \%$ & $27 \%$ & $35 \%$ & $39 \%$ & \\
\hline \multicolumn{6}{|l|}{ Refund anticipated ${ }^{d}$} \\
\hline Mean & $\$ 1,381$ & $\$ 1,362$ & $\$ 775$ & $\$ 958$ & 0.15 \\
\hline Standard deviation & $\$ 1,446$ & $\$ 1,567$ & $\$ 769$ & $\$ 1,080$ & \\
\hline Median & $\$ 648$ & $\$ 624$ & $\$ 500$ & $\$ 500$ & \\
\hline \multicolumn{6}{|l|}{ Refund received } \\
\hline Mean & No data & $\$ 1,377$ & $\$ 1,299$ & No data & 0.84 \\
\hline Standard deviation & No data & $\$ 1,536$ & $\$ 1,208$ & No data & \\
\hline Median & No data & $\$ 704$ & $\$ 700$ & No data & \\
\hline $\begin{array}{l}\text { Children in } \\
\text { household }^{\mathrm{e}}\end{array}$ & $52 \%$ & $51 \%$ & $50 \%$ & $40 \%$ & 0.86 \\
\hline $\begin{array}{l}\text { Receives public } \\
\text { assistance }^{f}\end{array}$ & $27 \%$ & $24 \%$ & $17 \%$ & $29 \%$ & 0.58 \\
\hline $\begin{array}{l}\text { Has health } \\
\text { insurance }\end{array}$ & $45 \%$ & $45 \%$ & $56 \%$ & $64 \%$ & 0.51 \\
\hline Owns home & $31 \%$ & $25 \%$ & $56 \%$ & $53 \%$ & 0.05 \\
\hline \multicolumn{6}{|l|}{ Gender } \\
\hline Female & $57 \%$ & $59 \%$ & $88 \%$ & $76 \%$ & 0.03 \\
\hline Male & $43 \%$ & $41 \%$ & $12 \%$ & $24 \%$ & \\
\hline \multicolumn{6}{|l|}{ Marital status } \\
\hline Currently married & $16 \%$ & $15 \%$ & $10 \%$ & $20 \%$ & 0.64 \\
\hline Not married & $84 \%$ & $85 \%$ & $90 \%$ & $80 \%$ & \\
\hline \multicolumn{6}{|l|}{ Employment status } \\
\hline Working full-time & $60 \%$ & $67 \%$ & $58 \%$ & $57 \%$ & 0.51 \\
\hline $\begin{array}{l}\text { Not working full- } \\
\text { time }\end{array}$ & $40 \%$ & $33 \%$ & $42 \%$ & $43 \%$ & \\
\hline
\end{tabular}


Table 4.9

(continued)

\begin{tabular}{|c|c|c|c|c|c|}
\hline & \multicolumn{2}{|c|}{ Participants } & \multicolumn{2}{|c|}{ Comparison } & \multirow{2}{*}{$\begin{array}{l}\mathrm{PF} \neq \mathrm{CF} \\
\mathrm{p}-\text { Value }\end{array}$} \\
\hline & Baseline & Follow-up & Follow-up & Baseline & \\
\hline \multicolumn{6}{|l|}{ Education } \\
\hline $\begin{array}{l}\text { Some college or } \\
\text { more }\end{array}$ & $49 \%$ & $48 \%$ & $25 \%$ & $51 \%$ & 0.09 \\
\hline $\begin{array}{l}\text { High school } \\
\text { diploma or less }\end{array}$ & $51 \%$ & $53 \%$ & $75 \%$ & $49 \%$ & \\
\hline \multicolumn{6}{|l|}{ Race } \\
\hline \multicolumn{6}{|l|}{$\begin{array}{l}\text { Asian, Black, } \\
\text { Hispanic, Native } \\
\text { American, }\end{array}$} \\
\hline Hawaiian, or other & $61 \%$ & $56 \%$ & $35 \%$ & $42 \%$ & 0.12 \\
\hline White & $39 \%$ & $44 \%$ & $65 \%$ & $58 \%$ & \\
\hline \multicolumn{6}{|c|}{ Panel B: planned uses of refund } \\
\hline Savings & $81 \%$ & $82 \%$ & $63 \%$ & $56 \%$ & 0.12 \\
\hline Debt repayment & $45 \%$ & $45 \%$ & $68 \%$ & $56 \%$ & 0.09 \\
\hline Spending & $57 \%$ & $49 \%$ & $58 \%$ & $58 \%$ & 0.51 \\
\hline$n$ & 75 & 41 & 22 & 53 & \\
\hline
\end{tabular}

Note: Sample sizes varies across variables due to missing data.

a Data on participants and comparison group members are presented for all individuals in each group with baseline data and for individuals in each group who completed a follow-up interview. The table reports demographic and financial information for members of each subgroup and compares the characteristics of baseline and follow-up participants and the characteristics of baseline and follow-up comparison group members. In addition, the last two columns give the results of statistical tests (including chi-square, Fisher's exact, and $t$-tests) comparing follow-up comparison group members to followup participants. Fisher's exact tests are two-sided.

${ }^{b}$ For participants, data on age are taken from Taxwise summary sheets. Comparison group data on age come from follow-up surveys and so are available only for comparison group members contacted on follow-up.

'Data on comparison group members' incomes were reported on the baseline survey in ranges. For participants, income equals AGI as reported on summary Taxwise page and then converted to ranges.

d Anticipated refund for participants is taken from Taxwise summary sheets. Anticipated refund data for comparison group members is from baseline surveys completed by respondents prior to having their taxes prepared.

ePercentage of respondents in each group reporting children under the age of 18 in household.

f Percentage of respondents in each group reporting currently receiving TANF, SSI, or food stamps. 
that the program was presented as a tool to encourage saving and the assumption that participants enrolled in the program because they believed it would in fact facilitate saving.

\subsection{Saving Outcomes for Participant and Comparison Groups}

Our first evidence on the short-term impact of R2A comes from comparing saving outcomes for the participant and comparison groups. We present data separately for planned savers (i.e., those who named a savings goal at baseline) and for all respondents. Limiting the sample to planned savers may reduce bias caused by differences in planned refund use across the two samples. In table 4.10, the outcome of interest is money from refunds still held in savings. Among planned savers, 72 percent of participants said that they were still saving part of their refunds, compared to 42 percent of the comparison group. This difference is statistically significant at the .10 level. Among all follow-up respondents, 66 percent of participants were still saving, compared to 36 percent of the comparison group. This difference is statistically significant at the .05 level. Mean differences in amount of refund still saved, either in dollar terms or as a percentage of the total refund amount, are not significant.

Next, we broaden our outcome measure to include using the refund on at least one stated savings goal, in addition to continuing to save a portion of the refund. A person who planned to save to purchase a car and, at follow-up, had done so would meet this broader definition of success. Someone who planned to save for the future and used part of her refund for an emergency also meets this definition. Table 4.11 shows that 78 percent of planned savers in the participant group were still saving some portion of their refund or had spent it on a stated savings goal. In the comparison group, 42 percent of planned savers met this criterion. Among all follow-up respondents (not just planned savers), 71 percent of participants met this criterion, compared to 36 percent of the comparison group. Both differences are significant at the .05 level. Again, mean differences in amount of refund still saved or spent on a savings goal are not significant. In sum, evidence regarding the short-term impact of R2A on saving part of a refund and achieving savings goals is positive but somewhat mixed: participants were more likely than comparison group members to save and spend on savings goals, but amounts saved and spent on savings goals did not differ significantly. 
Table 4.10

Saving out of Refund at Follow-up, for Participant and Comparison Groups ${ }^{a}$

\begin{tabular}{|c|c|c|c|c|c|c|}
\hline & \multicolumn{2}{|c|}{ Planned Savers ${ }^{b}$} & \multirow[b]{2}{*}{$\begin{array}{l}P \neq C \\
\text { p-Value }\end{array}$} & \multicolumn{2}{|c|}{ All Respondents ${ }^{c}$} & \multirow[b]{2}{*}{$\begin{array}{l}\mathrm{P} \neq \mathrm{C} \\
\mathrm{p}-\text { Value }\end{array}$} \\
\hline & $\begin{array}{l}\text { Partici- } \\
\text { pants }\end{array}$ & $\begin{array}{l}\text { Com- } \\
\text { parison }\end{array}$ & & $\begin{array}{l}\text { Partici- } \\
\text { pants }\end{array}$ & $\begin{array}{l}\text { Com- } \\
\text { parison }\end{array}$ & \\
\hline $\begin{array}{l}\text { Percentage sti } \\
\text { saving portion } \\
\text { of refund }\end{array}$ & $72 \%$ & $42 \%$ & 0.06 & $66 \%$ & $36 \%$ & 0.03 \\
\hline \multicolumn{7}{|c|}{ Amount saved } \\
\hline Mean & $\$ 423$ & $\$ 318$ & 0.75 & $\$ 338$ & $\$ 278$ & 0.78 \\
\hline $\begin{array}{l}\text { Standard } \\
\text { deviation }\end{array}$ & $\$ 1,041$ & $\$ 596$ & & $\$ 931$ & $\$ 550$ & \\
\hline Median & $\$ 50$ & $\$ 0$ & & $\$ 35$ & $\$ 0$ & \\
\hline Minimum & $\$ 0$ & $\$ 0$ & & $\$ 0$ & $\$ 0$ & \\
\hline Maximum & $\$ 4,000$ & $\$ 2,000$ & & $\$ 4,000$ & $\$ 2,000$ & \\
\hline \multicolumn{7}{|l|}{$\begin{array}{l}\text { Percentage of } \\
\text { refund saved }^{\mathrm{d}}\end{array}$} \\
\hline Mean & $24 \%$ & $21 \%$ & 0.72 & $21 \%$ & $19 \%$ & 0.74 \\
\hline $\begin{array}{l}\text { Standard } \\
\text { deviation }\end{array}$ & $31 \%$ & $29 \%$ & & $29 \%$ & $28 \%$ & \\
\hline Median & $11 \%$ & $0 \%$ & & $8 \%$ & $0 \%$ & \\
\hline Minimum & $0 \%$ & $0 \%$ & & $0 \%$ & $0 \%$ & \\
\hline Maximum & $100 \%$ & $83 \%$ & & $100 \%$ & $83 \%$ & \\
\hline$n$ & 32 & 12 & & 41 & 22 & \\
\hline
\end{tabular}

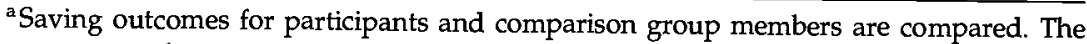
percentage of participants who planned to save and are still saving three to five months later is compared to that share of comparison group members doing so. The percentage of all participants (not just planned savers) who are still saving is also compared to the share of comparison group members doing so. Data on the amount of refund still saved and the percentage of the refund received still saved are presented for both planned savers and all follow-up respondents. Chi-square, Fisher's exact, and $t$-tests are used to test for significant differences among the groups. Fisher's exact tests are one-sided.

bPlanned savers are those who named a planned savings use of their refunds on the baseline survey.

'All respondents include those who completed a follow-up interview, regardless of whether they listed a planned savings use on the baseline survey.

${ }^{\mathrm{d}}$ Refund equals actual, not anticipated, refund amount. 
Table 4.11

Saving out of Refund or Spending on Savings Goals at Follow-up, for Participant and Comparison Groups ${ }^{\mathrm{a}}$

\begin{tabular}{|c|c|c|c|c|c|c|}
\hline & \multicolumn{2}{|c|}{ Planned Savers ${ }^{b}$} & \multirow[b]{2}{*}{$\begin{array}{l}P \neq C \\
p \text {-Value }\end{array}$} & \multicolumn{2}{|c|}{ All Respondents ${ }^{c}$} & \multirow[b]{2}{*}{$\begin{array}{l}P \neq C \\
p \text {-Value }\end{array}$} \\
\hline & $\begin{array}{l}\text { Partici- } \\
\text { pants }\end{array}$ & $\begin{array}{l}\text { Com- } \\
\text { parison }\end{array}$ & & $\begin{array}{l}\text { Partici- } \\
\text { pants }\end{array}$ & $\begin{array}{l}\text { Com- } \\
\text { parison }\end{array}$ & \\
\hline $\begin{array}{l}\text { Percentage still } \\
\text { saving portion } \\
\text { or having spent } \\
\text { on savings goal }\end{array}$ & $78 \%$ & $42 \%$ & 0.02 & $71 \%$ & $36 \%$ & 0.01 \\
\hline $\begin{array}{l}\text { Amount saved } \\
\text { or spent on } \\
\text { savings goals }\end{array}$ & & & 0.80 & & & 0.88 \\
\hline Mean & $\$ 472$ & $\$ 568$ & & $\$ 376$ & $\$ 415$ & \\
\hline $\begin{array}{l}\text { Standard } \\
\text { deviation }\end{array}$ & $\$ 1,065$ & $\$ 1,192$ & & $\$ 956$ & $\$ 943$ & \\
\hline Median & $\$ 53$ & $\$ 0$ & & $\$ 50$ & $\$ 0$ & \\
\hline Minimum & $\$ 0$ & $\$ 0$ & & $\$ 0$ & $\$ 0$ & \\
\hline Maximum & $\$ 4,000$ & $\$ 3,900$ & & $\$ 4,000$ & $\$ 3,900$ & \\
\hline \multicolumn{7}{|l|}{$\begin{array}{l}\text { Percentage of } \\
\text { refund saved } \\
\text { or spent on } \\
\text { savings goals }\end{array}$} \\
\hline Mean & $32 \%$ & $27 \%$ & 0.66 & $27 \%$ & $22 \%$ & 0.56 \\
\hline $\begin{array}{l}\text { Standard } \\
\text { deviation }\end{array}$ & $36 \%$ & $37 \%$ & & $34 \%$ & $32 \%$ & \\
\hline Median & $13 \%$ & $0 \%$ & & $10 \%$ & $0 \%$ & \\
\hline Minimum & $0 \%$ & $0 \%$ & & $0 \%$ & $0 \%$ & \\
\hline Maximum & $100 \%$ & $98 \%$ & & $100 \%$ & $98 \%$ & \\
\hline$n$ & 32 & 12 & & 41 & 22 & \\
\hline
\end{tabular}

a Saving outcomes for participant and comparison groups are compared, first for planned savers, then for all respondents. Chi-square, Fisher's exact, and $t$-tests are used to test for significant differences between the groups. Fisher's exact tests are one-sided.

bplanned savers are defined as those who named a planned savings use of their refunds on the baseline survey.

'All respondents include all individuals who completed a follow-up interview, regardless of whether they listed a planned savings use on the baseline survey.

d Refund equals actual, not anticipated, refund amount. 


\subsection{Bank-Level Account Data}

In addition to self-reported data, we obtained bank balance and transaction data for participants from the Bank of Oklahoma. BOk provided individual data for participants who either opened new savings accounts with BOK or who split their refunds into existing BOk accounts. The data include account status, monthly account balance information for August through November 2004, limited account-level data on transactions, and household-level data on the ownership of BOK products. These data were not available for comparison group members.

BOk located account data for fifty-eight out of the sixty-six individuals who either opened an account with BOK or split to an existing account. (These fifty-eight individuals represent 77 percent of all R2A participants.) Of these fifty-eight, 62 percent still had active BOk accounts by mid-August 2004, but 38 percent had closed their accounts, either at their request or due to bank policy, which closes zero-balance accounts. (The bank provided no additional information on these closed accounts and account-holders.) The 62 percent with still-open accounts kept their accounts open at least through November 2004, when BOk provided data to the research team.

Participants with open accounts generally received larger refunds and had higher incomes than participants with closed accounts. Apart from these differences, there were no significant differences between the two groups on other demographic variables. Participants with open accounts appeared to have greater familiarity with savings accounts (33 percent had a savings account at another financial institution, compared to 22 percent of those with closed accounts), but the difference is not statistically significant. The two groups appear almost identical in terms of R2A services used (splitting, account opening, or both) and checking account ownership.

For participants who still had accounts open in November 2004, BOk provided household-level data on other relationships these individuals had with the bank. As we would expect, all of these households owned some kind of savings vehicle at BOk. (Ninety-seven percent had savings accounts, 8 percent had money market accounts, and 3 percent held IRAs at BOk.) Only 16 percent had ATM cards. Half of the households had a checking account of some kind, including a mix of standard checking accounts, free or "second chance" checking accounts, and even high-end products with high balance requirements (though the balances on these accounts were quite small and so the account 


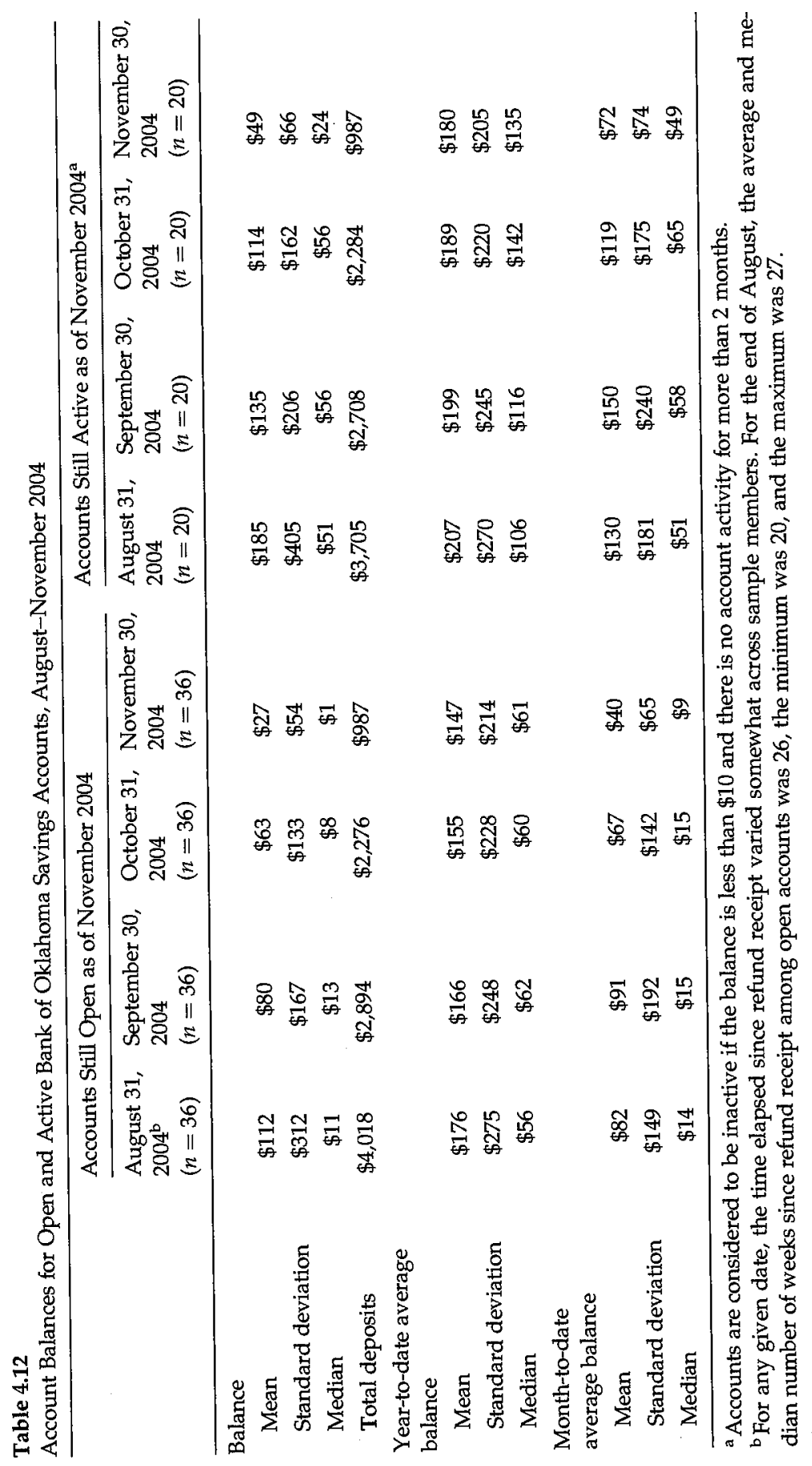


holders were probably paying account fees). Only 8 percent of these households held any debt with BOk. (Three percent had installment loans, and 5 percent had mortgages.)

Some of these checking accounts, debt products, and investment accounts appear to pre-date the tax season. However, approximately 56 percent of this subset of households did not have a relationship with BOk prior to the tax season, so the initial savings accounts generated new customers for the bank. Furthermore, one-quarter of these new R2A-BOK customers opened additional accounts (beyond the savings account) following the tax season, suggesting meaningful crossselling opportunities within the R2A participant sample. ${ }^{31}$

BOK provided end-of-month data on savings account balances for August, September, October, and November 2004 for accounts remaining open in mid-August. These data show that participants rapidly withdrew money from their accounts. This subsample of participants initially deposited an average of $\$ 644$ into their BOk accounts. The average balance dropped to $\$ 112$ by August (twenty-six weeks after refund receipt for most participants) and to $\$ 27$ by November (thirtyeight weeks after refund receipt for most participants). The median balance of $\$ 203$ at enrollment dropped to $\$ 11$ in August and $\$ 1$ in November. Although thirty-six accounts were still open in November, at least sixteen of those might be considered inactive: they had balances of less than $\$ 10$ and no activity for at least two months. As detailed in table 4.12 , excluding these inactive accounts from the balance calculations yields higher average and median balances but a substantially higher account closure rate.

\subsection{Saving Outcomes for Participants With and Without R2A}

Further evidence on the short-term impact of R2A comes from data on saving part of refunds by participants in 2003, the year before R2A was available. In the baseline survey, we asked R2A participants whether they had received a federal refund in the previous year. We asked those who did receive a refund in 2003 whether they were still saving a portion three months after they received their refunds. We compared these data with data on savings at follow-up in 2004, when participants used R2A services. We use a McNemar chi-square to test for significant differences across time among the participants responding to both the baseline question and the follow-up survey $(n=31)$. Participants report a higher propensity to save with $\mathrm{R} 2 \mathrm{~A}$ relative to the prior year, when R2A was not available, a relationship that is highly significant $(\mathrm{p}<.01) .^{32}$ 
Table 4.13

Responses to Follow-up Survey Attitudinal Questions for Participants, by Participation Status $^{a}$

\begin{tabular}{lccc}
\hline & $\begin{array}{l}\text { Split Refund } \\
\text { to New or } \\
\text { Existing } \\
\text { Account }\end{array}$ & $\begin{array}{l}\text { Did Not } \\
\text { Split (New } \\
\text { Account } \\
\text { Only) }\end{array}$ & $\begin{array}{l}\text { All } \\
\text { Participants }\end{array}$ \\
$\begin{array}{l}\text { Service helped to save more of } \\
\text { refund }\end{array}$ & $89 \%$ & $63 \%$ & $83 \%$ \\
$\begin{array}{l}\text { Service helped to spend refund } \\
\text { more slowly }\end{array}$ & $82 \%$ & $88 \%$ & $83 \%$ \\
$\begin{array}{l}\text { Service helped to resist spending } \\
\text { temptations }\end{array}$ & $76 \%$ & $75 \%$ & $76 \%$ \\
$\begin{array}{l}\text { Would split next year } \\
\text { Would still split even if had to } \\
\text { wait longer for refund }\end{array}$ & $97 \%$ & $75 \%$ & $92 \%$ \\
$\begin{array}{l}\text { Would recommend service to a } \\
\text { friend }\end{array}$ & $87 \%$ & $100 \%$ & $89 \%$ \\
$\begin{array}{l}\text { Average amount willing to pay } \\
\text { to split refund }\end{array}$ & $100 \%$ & $\mathrm{NA}$ & $\mathrm{NA}$ \\
$n$ & $\$ 6.60$ & $\mathrm{NA}$ & $\mathrm{NA}$ \\
\hline
\end{tabular}

a Participants were asked a series of questions designed to gauge their satisfaction with R2A and their feelings about the program's effectiveness. Participants were also asked several questions about possible future use of a splitting service. Responses are presented for participants who split their refunds, for participants who did not split their refunds, and for all participants.

bSplitters were asked if they planned to split their refunds again next year. For nonsplitters, the concept of the splitting service was explained, and they were then asked if they would split their refunds next year.

'Respondents (both splitters and non-splitters) who stated that they would split their refunds again next year were asked if they would still plan to split even if their refunds arrived more slowly as a result. Respondents who did not plan to split next year were not asked this question.

\subsection{Participant Perceptions of R2A}

A final source of evidence regarding the impact of R2A comes from responses to attitudinal questions included in the follow-up survey, displayed in table 4.13. The survey data suggest that R2A facilitated saving and thoughtful spending. Eighty-three percent of respondents said that the service helped them save more, 83 percent said that the service helped them spend their refunds more slowly, and 76 percent said that the service helped them resist spending temptations. In addition, all respondents said that they would recommend R2A to a friend, and 97 percent planned to split their refunds again next year. On aver- 
age, participants were willing to pay $\$ 6.60$ to split their refunds, and 89 percent were willing to split even if they had to wait longer to receive their refunds. These results suggest that participants perceived material benefits from the service, albeit not necessarily related to longterm savings goals.

\section{Discussion}

We willingly concede that this research has important limitations. This is a small study in a single location with a set of taxpayers that may not be representative of the LMI population in the United States. In addition, findings related to the impact of the program must be interpreted very cautiously because individuals were not randomly assigned to treatment and control groups, and the comparison group examined here probably differs from the treatment group in important (and unmeasured) ways. Nevertheless, we offer some tentative conclusions. Most are best viewed as hypotheses for future study rather than as conclusions in their own right. We also suggest some directions for future research.

Refund splitting seems to appeal to LMI families. When we began this experiment, the team was prepared for the possibility that no one would want to use this new, untested service. We offered people a service that involved their money, where few had advance notice of the service, where there was no word of mouth, and where refund recipients had to fill out additional paperwork in order to participate. We were surprised that demand was as strong as it was: 27 percent of refund recipients wanted to use the service. Afterwards, almost all participants said they were satisfied with the service and would use it again, and they were willing to pay an average of $\$ 6$ for the splitting service. While it will take other experiments at other sites to confirm these results, our data suggest that refund splitting could meet with very strong consumer demand among LMI families.

LMI families are most interested in splitting into basic financial products, but other products have some appeal. In our follow-up survey, we asked participants which financial products they would like to split into (see table 4.14). There was greater demand for simpler financial products, with 92 percent very likely or likely to select a savings account; 88 percent, a checking account; and 65 percent, a paper check. There was also interest in retirement savings products (53 percent); college savings products (51 percent); and, to a lesser extent, certificates of deposit, 
Table 4.14

New Splitting Options, Participant Interest in Additional Products ${ }^{a}$

\begin{tabular}{lccc}
\hline & $\begin{array}{l}\text { Very } \\
\text { Likely }\end{array}$ & $\begin{array}{l}\text { Somewhat } \\
\text { Likely }\end{array}$ & Combined \\
\hline Savings & & & \\
Savings account & $66 \%$ & $26 \%$ & $92 \%$ \\
Retirement savings & $14 \%$ & $39 \%$ & $53 \%$ \\
College savings & $27 \%$ & $24 \%$ & $51 \%$ \\
Certificate of deposit & $12 \%$ & $17 \%$ & $29 \%$ \\
US savings bond & $7 \%$ & $17 \%$ & $24 \%$ \\
Mutual fund & $9 \%$ & $12 \%$ & $21 \%$ \\
Transaction & & & \\
Checking account & $63 \%$ & $25 \%$ & $88 \%$ \\
Paper check & $25 \%$ & $40 \%$ & $65 \%$ \\
Stored value card & $15 \%$ & $25 \%$ & $40 \%$ \\
International remittance & $8 \%$ & $14 \%$ & $22 \%$ \\
Debt & & & \\
Car loan & $20 \%$ & $25 \%$ & $45 \%$ \\
Credit card & $32 \%$ & $12 \%$ & $44 \%$ \\
Mortgage & $25 \%$ & $17 \%$ & $42 \%$ \\
\hline
\end{tabular}

a Participants and comparison group members $(n=60)$ were asked how likely they would be to split their refunds into a number of different financial products. Respondents were given four response options: "very likely," "somewhat likely," "somewhat unlikely," and "very unlikely." This table aggregates participant and comparison group member responses and presents the results for the "very likely" and "somewhat likely" responses, and combines them in the right-hand column.

b The stored value card was described to respondents as "a card that you could use at an ATM/Transfund machine, like a debit card."

savings bonds, and mutual funds. ${ }^{33}$ Families also expressed a demand for a splitting service that directly paid down various debts (car loan45 percent, credit card -44 percent, and mortgage -42 percent). Finally, more than one-fourth of respondents expressed interest in a splitting service that would allow them to send international remittances. ${ }^{34}$ While some of these remittances would likely be spent by recipients, it appears that some remitted funds are used for asset building, including home construction and improvement (Thompson 2002).

Lack of access to low-cost savings vehicles could substantially limit actual rates of refund splitting by $L M I$ families. In our experiment, participants either split into existing accounts, split into new accounts, or opened new accounts without splitting. If we had limited the service to those who could split into existing accounts, our participation rate would 
have been considerably lower. In the R2A pilot, only 27 percent of the participants split into existing accounts, with the remainder opening accounts. Slicing the data another way shows that the demand for splitting alone (4 percent) was less than one-half the demand for splitting coupled with account opening (8 percent). The ChexSystems screen appears to have been a significant barrier to participation. In our experiment, potential participants foiled by ChexSystems had completed almost all of the required paperwork and clearly had strong demand for the service. Had we been able to offer them a savings vehicle, we could have increased our splitting participation rate from 12 percent to 19 percent. ${ }^{35}$ While some tax preparation sites have succeeded in convincing bank partners to waive ChexSystems requirements for refund depositors, these individual agreements have affected a relatively small number of filers.

Although BOk did not waive the ChexSystems screen, the bank did forgo the $\$ 100$ initial-deposit requirement and the $\$ 300$ minimumbalance requirement for participants. This encouraged participation in R2A, but it will not be possible to take splitting to scale if program administrators must depend on the goodwill of individual financial institutions to waive requirements of this sort.

To implement splitting, one must address material operational concerns, which might suggest that this process be administered centrally by the IRS. Our paper primarily deals with the participant experience with the splitting service, not the operational complexities of offering it. Yet R2A changed the flow of the tax-preparation site because account opening required an additional step with different personnel. It also required monitoring refund transmissions from the IRS, transferring funds according to splitting instructions, and responding to user inquiries.

While a large commercial preparer could accommodate an R2A-like program, ${ }^{36}$ our approach would not work for self-preparers or thinly staffed tax-preparation sites. As much as one-third of all LMI returns are self-prepared, and we suspect that a meaningful fraction of the volunteer tax-preparation sites (which process 1 to 3 percent of LMI returns) might be operationally challenged by the requirements to open accounts on site. ${ }^{37}$

If splitting is sensible, then from an operational perspective, it can be accomplished either at the destination or at the source. Destinationbased splitting - in the R2A fashion or as currently offered to higher net worth customers-would require the participant to instruct her financial institution or agent to disburse her refund in a certain fashion 
once it was received from the IRS. Source-based splitting would provide instructions to the sender of the refund, the IRS, to split it to multiple destinations. Both of these approaches could coexist, but there are operational considerations that make source-based splitting appealing. Splitting instructions could be integrated into the tax preparation process seamlessly, as just another destination for refunds. There would be no need for private parties to coordinate with the IRS to track refunds. Perhaps more important for LMI filers, source-based splitting would ensure that the service was available to all, regardless of the financial institution with which they do business.

Apparently, current policy makers have reached this conclusion. The Bush administration has included a splitting proposal in its budget for the last two years. On January 31, 2005, twelve members of Congress wrote to IRS Commissioner Everson, requesting that the IRS adopt technical changes that would enable splitting. On March 25, 2005, Commissioner Everson replied that the IRS was "working toward making this program available as quickly as possible" and set a deadline of the 2007 filing season.

This model of refund splitting may provide business opportunities for private tax preparers. Currently, many private tax preparers, including large companies such as H\&R Block and Jackson Hewitt, but also smaller businesses, derive substantial revenue from the sales of refund-related financial products. To date, these have mostly included short-term loans, commonly called refund anticipation loans (RALs), which allow refund recipients to access their funds several days faster than would be possible with standard direct deposit. While H\&R Block was the first company to offer RALs, they are now widely available, and several of the larger tax preparation firms have begun to introduce stored value card (SVC) products that allow refund recipients to receive their funds on a plastic card, similar to a debit card.

Refund splitting could encourage the sale of more than one refundrelated product to a single consumer. For example, a refund recipient might purchase an SVC and also open a savings account, splitting her refund between the two. Multiple-product purchase could both increase revenue and build the relationship between tax preparer and client, reducing costly client acquisition activity (Tufano and Schneider 2005). A well-executed splitting program could also serve as a source of differentiation in the highly competitive tax preparation sector.

Rather than build a business about accelerating spending, a preparer could capitalize on its customers desire to slow down spending by sav- 
ing. One might fear that preparers might offer inferior products to lowincome savers. In part, this concern would be addressed by rules that would subject the preparers or their business partners to NASD suitability rules or "know your customer" regulations in banking, depending on the type of product they offered to consumers. Competition could also address this concern in the long run if preparers competed on the basis of offering attractive savings products. However, savers' interests could be protected by offering all refund savers a baseline product that could serve as a floor or default, yet encourage private preparers to offer products with terms at least as favorable or better.

In particular, Tufano and Schneider (2005) discuss permitting refund recipients to purchase U.S. savings bonds with their refunds. Twentyfour percent of follow-up survey participants said they would be likely to purchase savings bonds with part of their refund (table 4.14). Another survey question described savings bonds (rather than simply naming them), and 76 percent of respondents said they would be likely to purchase bonds. ${ }^{38}$ While the data suggests that refund recipients might like to direct their money to many alternatives, this would ensure that there was at least one savings alternative available to all. No customer would be captive to just the products that their preparer offered. In addition, the savings bond's terms would serve as a lower bound for any private product. Whether this would spur private savings products or crowd them out is an empirical question.

There are many opportunities for related research and evaluation. Our study is admittedly a small-scale experiment, yet it can offer some hypotheses for future study. In particular, we are intrigued by the comparison of our results with those obtained in the St. Louis study (Duflo et al. 2005), cited earlier, which differed from ours in a few key dimensions. Our experiment uses a simple savings vehicle, whereas the St. Louis team directed savings into an IRA product. Our experiment provided greater liquidity, while theirs provided less liquidity and greater precommitment. The two products seem to have appealed to individuals with differing (though complementary) savings goals. Many R2A participants reported planning short-term savings for emergencies, while the Express IRA participants generally focused on longer-term retirement savings. Both are legitimate savings goals.

Our savings program offered little explicit financial inducement to participate, apart from waiving minimum balance requirements and monthly fees. The St. Louis experiment provided substantial financial 
incentives for participation, in the form of matching funds: Participants were randomly selected to be offered a 50 percent match, a 20 percent match, or no match. Those who were not offered a match had the lowest participation rates ( 3.3 percent) and contributed the smallest amount on average (\$28). Interestingly, St. Louis filers who were offered the 50 percent match on the less-liquid IRA product had a very similar take-up rate (17 percent) compared to participants in the R2A study (15 percent) who were offered liquid accounts with no match (Duflo, Gale, Liebman, Orszag, and Saez 2005). Comparing the two results may give a sense about the size of the compensation required to induce long-term savings.

While it may be appropriate to encourage long-term savings, this cannot come at the expense of acknowledging other shorter-term savings goals. If we examine the R2A program from the perspective of consumer satisfaction or self-reported ability to better manage finances, it looks attractive. Measured narrowly using data on account balances, the results are far less impressive because balances were rapidly drawn down. Our small experiment suggests that this service cannot be evaluated simply by looking at the size of a participant's bank balance. While savings account balances dropped significantly over our nine-month study, participants saved portions of their refunds for longer periods of time than individuals not offered the service. Perhaps the relevant measure of success is not account balance, but whether the participant is making progress toward-or has achieved-her financial goals. Emergency saving is a legitimate savings goal for families, as is saving for auto repair, if that car helps an individual keep his job. If the program helps participants to weather emergencies or keep their cars functioning and hence maintain employment, then the program. cannot be judged a failure because savings balances are depleted. Although accumulating and protecting long-term savings (say, for retirement) are important goals, there are other critical savings goals for LMI families. Any program must be measured against the participants' goals.

Our results suggest that a program of splitting with account opening might generate strong interest among LMI families. By forcing families to think about their refunds before they receive them, they may find it easier to save and to resist spending temptations. Participants seem. to have a somewhat better-or no worse-post-refund track record than other families. Future studies should further test the impact of programs like R2A, further unbundling the effects of account opening 
from splitting. In addition, while we have examined a limited set of account data, future work should look more closely at account-level transaction and balance data to understand how low-income filers use their accounts and the consequences of those use patterns for bank profitability. More generally, all of these first findings should be replicated with larger samples, where it would be possible to go further, to understand the product mix, features, and marketing activities that would best support savings by low- and moderate-income families.

\section{Notes}

We would like to thank the Annie E. Casey Foundation; the Community Action Project of Tulsa County; Doorways to Dreams Fund (D2D Fund); the Bank of Oklahoma; and the participants from the Pine and Lewis, Houston Center, and 21st Street tax preparation sites in Tulsa, Oklahoma, for allowing us to conduct this study. In particular, we would like to thank the team consisting of Monica Armstrong, Kim Cowden, Steven Dow, Brandy Holleyman, Tim Flacke, and Jeff Zinsmeyer, who helped plan and carry out this experiment. We would also like to thank Lily Bachelder, Michael Barr, Colleen Dailey, Stephen Dow, Fred Goldberg, John Gourville, Derek Martin, David Rose, Reggie Stanley, Mike Stegman, Anne Stuhldreher, Jen Tescher, Heather Tyler, John Zinman, as well as participants at the NBER Tax Policy and the Economy Conference, the National Community Tax Coalition/Annie E. Casey 3rd Annual Conference, and the 2004 IDA Learning Conference for their comments on this work. Toni Wegner and David Hann assisted us in the IRB approval processes. Financial support for this research project was provided by the Division of Research of the Harvard Business School, the Annie E. Casey Foundation, and D2D Fund. We thank them for their support but acknowledge that the findings and conclusions presented in this report are those of the authors alone and do not necessarily reflect the opinions of the Annie E. Casey Foundation, Harvard Business School, or D2D Fund.

1. In fall 2004, all three of the top-selling books on personal finance at Amazon.com emphasized the concept of "paying yourself first." See Kiyosaki and Lechter (2000), Bach (2003), and Clason (1988).

2. We define LMI as having adjusted gross income (AGI) of less than $\$ 30,000$.

3. Authors' calculations based on published Internal Revenue Service (IRS) data. The 2001 figures are derived from estimates prepared by the Statistics of Income Division of the IRS and are based on calendar year. Total refunds is the sum of all refunds to filers with AGI of less than $\$ 30,000$.

4. Authors' calculations based on data from Internal Revenue Service, Statistics of Income (2001).

5. Our research project roughly followed the action research cycle of problem definition, pilot program implementation, evaluation, and re-test. See Lewin (1948) and Kemmis and McTaggert (1988).

6. The Bank of Oklahoma is a subsidiary of the Bank of Oklahoma Financial Corporation (BOKF). BOKF operates banks in Oklahoma, Texas, New Mexico, Arkansas, and 
Missouri. It is the largest bank in Oklahoma, with $\$ 5.9$ billion in deposits, more than twice that of BancFirst, its closest competitor in the market. See www.bokf.com.

7. See, for example, Schreiner, Clancy, and Sherraden (2002); Sherraden and Barr (2004); and Hubbard and Skinner (1996).

8. This decline is less dramatic, though generally still evident, when alternative approaches to measuring the saving rate are used, such as those employed by Parker (1999) and Gale, Sabelhaus, and Hall (1999). Borsch-Supan and Lusardi (2003) use data from the Organisation for Economic Co-operation and Development (OECD) to show that the saving rate in the United States is significantly below that of most European countries and Japan.

9. The EITC is available to low-income tax filers (individuals or families) with earnings. It is intended primarily for parents of children under age 19, but low-income workers without children may receive a small credit. The amount of the credit initially rises with earnings, then reaches a plateau, and finally decreases with each additional dollar earned. See Center on Budget and Policy Priorities (2004) for details. The maximum credit for tax year 2003 was $\$ 4,204$.

10. The CTC is a federal tax credit for each dependent under age 17. For tax year 2003, the credit was worth a maximum of $\$ 1,000$ per child. Filers with taxable earned income above $\$ 10,500$ were eligible for a refundable credit. See Lee and Greenstein (2003) for details. When a credit is refundable, any portion of the credit that exceeds tax liability is transferred to the tax filer as an income tax refund.

11. At VITA sites, savings accounts have generally been offered through partnerships between the community organizations running the tax-preparation sites and banks or credit unions. The terms of these accounts vary, with financial institutions occasionally waiving fees, minimum balances, or ChexSystems requirements (discussed in more detail in section 4 of this paper). Product marketing differs across programs as well. At some sites, bank representatives are on-site and actively promote the accounts. At others, VITA staff may be responsible for selling the accounts and are required to call in to a partner bank to set up the account remotely. There also appears to be considerable variability in the success of these programs. Some practitioners have found that few participants are interested in opening accounts and that those who do open accounts deplete these accounts quickly; other programs have seen greater success. This assessment is based on phone interviews with staff from nine free tax-preparation sites and reports from two other taxpreparation sites. Interviews were conducted during April 2004 with staff at The Baltimore CASH Campaign (Baltimore, Md.), the Piton Foundation (Denver, Colo.), The Milwaukee EITC/Asset Building Project (Milwaukee, Wis.), Alternatives Federal Credit Union (Ithaca, N.Y.), The Central City Asset Building Coalition (New Orleans, La.), The Riverside Family Asset Building Program (Riverside, Calif.), The United Way of King County (Seattle, Wash.), The Center for Economic Progress (Chicago, Ill.), The Nehemiah Gateway CDC (Wilmington, Del.). Reports from the Boston EITC coalition (Boston, Mass.) and the Community Food Resource Center (New York, N.Y.) were also used.

12. In 1998, Richard Thaler and Shlomo Benartzi implemented the first test of the Save More Tomorrow plan (SMarT) (Thaler and Benartzi 2004). The SMarT plan allowed workers to precommit to automatically save their 3 percent annual raises in the company pension plan. Of 286 employees who met with an investment advisor, 162 enrolled in the program. After twenty-eight months, these employees had increased their saving rates from an average of 3.5 percent to 11.6 percent of income. A comparison group of employees who did not precommit to save their raises, but who did agree to try to increase their 
savings without an automatic feature, increased their saving rates from only 4.4 percent to 8.7 percent.

13. Prior to tax filing, would-be splitters file a form with Vanguard outlining the allocation of their refunds. These filers then submit a general Vanguard account number and routing number on their tax return, and Vanguard automatically splits the refund deposited into this account according to the previously issued instructions. Additional information on Vanguard's splitting policy is available at http://flagship2.vanguard.com/ VGApp/hnw/TcDirectDepositController?cbd (accessed March 3, 2004).

14. This statement is based on phone interviews conducted in March 2004 with representatives from the nation's ten largest banks and largest mutual funds by assets.

15. Seventy-two of the 500 largest mutual funds by assets as reported by Morningstar were Vanguard funds. Of these, only one fund had a minimum initial investment of less than $\$ 1,000$.

16. Individual development accounts were first proposed by Sherraden (1991). They are matched savings accounts for low-income people and are designed to encourage asset building.

17. In the interest of full disclosure, we note that one of the researchers is the founder and chair of D2D Fund.

18. These accounts earned the same interest rate as other basic BOk savings accounts (.5 percent per annum at the time of the study). However, BOK waived the $\$ 100$ openingdeposit requirement. The bank also waived minimum-balance requirements and associated fees for accounts in this program. Had these requirements not been waived, account holders would have been charged $\$ 6$ per quarter on accounts with balances of less than $\$ 300$.

19. Clients were also asked, but not required, to sign a research consent form.

20. Postcards announcing the program were mailed in January 2003 to 3,200 clients of CAPTC, but this mailing was ineffective and generated virtually no detectable response.

21. Copies of survey instruments are available from the authors.

22. The take-up rate may have been higher in R2A because participants who have used other CAPTC services in the past and have a favorable opinion of the organization might be more likely to use another CAPTC service. However, CAPTC reports that tax clients do not generally identify the free tax preparation service with CAPTC.

23. While research on the impact of ChexSystems (and similar) credit scoring services on banking participation by the poor is limited, BOk's practices are probably the norm among banks. However, some depository institutions waive ChexSystems either as a general rule or in the specific instance of targeted saving programs.

24. We ran several logistic regression models to identify predictors of take-up. Findings were not robust, so we cannot say whether differences that were significant in a bivariate framework would remain significant when other differences were controlled.

25. The American Dream Demonstration (ADD) project, a national study of IDA programs, found that participants with the lowest incomes had the highest average saving rates. However, regression analysis on ADD participants did not find that income had a significant effect on the likelihood of being a saver (defined as saving a specified minimum over the life of the program). The ADD research also found that having health 
insurance was positively related to being a saver (Schreiner, Clancy, and Sherraden 2002), but our findings suggest that health insurance is negatively related to R2A enrollment.

26. In 2003, the unemployment rate in Tulsa was 6.5 percent, the highest annual rate in fifteen years (Bureau of Labor Statistics, U.S. Department of Labor 2004).

27. These decliners chose the following response option: "I'd be interested if there was a match or if there was an option to save for a specific purpose." It is unlikely that individuals would have given this response to an open-ended question. Still, these responses suggest that the service, as delivered, was not attractive enough to elicit participation.

28. The per capita data is restricted to those participants who responded to the survey item on existing savings and for whom there is data on the amount of the refund sent to savings $(n=68)$.

29. We attempted to reach participants and comparison group members multiple times over the follow-up period. Only two of those contacted refused to complete the followup survey. It seems unlikely that participants who did not save disproportionately avoided the follow-up interview.

30. Data on anticipated refund amounts come from different sources for the two groups. Comparison group members were asked to estimate refund amounts before tax preparation began. For participants, data were taken from the Taxwise software after tax preparation was completed.

31. Data are not available on the types of accounts opened or how many accounts each household opened. Among all participant households that kept their accounts open through November (not just new BOk customers), 19 percent (7) purchased new products after the tax season.

32. There are three important data quality issues in addition to the small sample. First, respondents may have been unable to accurately recall refund uses for 2003 . Since the R2A outreach emphasized the value of saving, we assume that over-reporting of saving in 2003 was more common than under-reporting. If this is true, our test is conservative, all else equal. Second, we cannot account for changes in economic or personal circumstances that would affect the use of a refund. The final issue involves mismatch in timing. For saving in 2003, each person was asked to report whether she was saving three months after refund receipt. For saving in 2004, each follow-up survey respondent was asked whether she was currently saving some portion of the refund, and the timing of followup surveys varied from three months to five months after refund receipt. Again, this data flaw is likely to make our test more conservative because people are less likely to have some of the refund in savings as time passes.

33. Our experiment allowed refund recipients to invest only in a completely liquid vehicle-a standard savings account. Participants who wanted a less liquid product, such as a certificate of deposit or a savings bond, may have chosen not to split. In future research, it would be useful to examine the demand for less liquid products, which may encourage and facilitate longer-term saving and financial planning.

34. It is possible that our survey underestimated demand for this service in the wider market. A large portion of the remittances sent abroad from the United States are directed to Latin America. The most likely senders of these remittances, Hispanics, were under-represented in our sample because we did not recruit participants at CAPTC's Spanish-language tax-preparation site. 
35. The splitting participation rate is calculated as the number of splitters (62) divided by the number of individuals approached expecting a refund (516). The participation rate had ChexSystems not been used is calculated as the number of participants splitting (62) and the number denied by ChexSystems (36) divided by the number of individuals approached expecting a refund (516).

36. H\&R Block has offered two programs in which a participant can open either an IRA or a savings account at the time of filing (Tufano and Schneider 2005) and effectively offers splitting services.

37. Wojciech Kopczuk and Cristian Pop-Eleches use 1999 SOI data to report that 67 percent of EITC eligible families used a professional tax preparer. See Kopczuk and PopEleches, "Electronic Filing, Tax Preparers, and Participation in the Earned Income Tax Credit," Columbia University working paper, March 2005, http://www.columbia.edu/ $\sim$ wk2110/bin/efile.pdf (last accessed May 30, 2005). Data on the size of the VITA market is drawn from "Tax Administration: IRS's 2003 Filing Season Performance Showed Improvements," 2003, United States General Accountability Office (GAO); National Taxpayer Advocate 2004 Annual Report to Congress, 2004, Taxpayer Advocate Services, Internal Revenue Service; Internal Revenue Service, "Tax Stats," http://www.irs.gov/taxstats/; Internal Revenue Service, Statistics of Income, 2001, Individual income tax statistics2001, Table 3.3-2001: Individual income tax, all returns: Tax liability, tax credits, tax payments, by size of adjusted gross income, http://www.irs.gov/pub/irs-soi/01in33ar .xls.

38. Specifically 76 percent of those surveyed answered yes to the following: "Most savings accounts in banks currently pay about 1 percent interest. Suppose you could send part of your refund to save in a savings bond that paid 3.4 percent but wouldn't allow you to withdraw the money for several months. Would you consider sending part of your refund to save in a savings bond?" The rates we quoted in the survey question were representative of those offered at the time through bank accounts and savings bonds.

\section{References}

Aizcorbe, Ana M., Arthur B. Kennickell, and Kevin B. Moore (2003). "Recent Changes in U.S. Family Finances: Evidence from the 1998 and 2001 Survey of Consumer Finances," Federal Reserve Bulletin, 89:1-32.

Ashraf, Nava, Dean S. Karlan, and Wesley Yin (2006). "Tying Odysseus to the Mast: Evidence from a Commitunent Savings Product in the Philippines," Quarterly Journal of Economics.

Bach, David (2003). The Automatic Millionaire: A Powerful One-Step Plan to Live and Finish Rich. New York: Broadway.

Barrow, Lisa, and Leslie McGranahan (2000). "The Effects of the Earned Income Credit on the Seasonality of Household Expenditures," National Tax Journal, 53(4):1211-1243.

Beverly, Sondra G., Amanda Moore, and Mark Schreiner (2003). "A Framework of Asset'Accumulation Stages and Strategies," Journal of Family and Economic Issues, 24(2):143-156.

Beverly, Sondra G., Jennifer Tescher, Jennifer L. Romich, and David Marzahl (2002). "Linking Tax Refunds and Low-Cost Bank Accounts: Findings from the Extra Credit Savings Program," Joint Center for Poverty Research, Chicago, Ill., working paper no. 277. 
Borsch-Supan, Axel, and Annamaria Lusardi (2003). "Saving: A Cross-National Perspective," in Axel Borsch-Supan (ed.), Life-Cycle Savings and Public Policy: A Cross-National Study of Six Countries. San Diego, Calif.: Elsevier Science.

Brookmgs Institution (2004). "Proceedings of Filling the Savings Gap: How to Get Moderate-Income Households to Save for Retirement," http://www.brook.edu/comm/ events/20040517.pdf.

Bureau of Economic Analysis, U.S Department of Commerce (2004). "National Income and Products Accounts," Table 2.9: Personal Income and Its Disposition by Households and by Nonprofit Institutions Serving Households, U.S Department of Commerce website, http://www.bea.gov/bea/dn/nipaweb/TableView.asp?SelectedTable=294\& FirstYear=2001\&LastYear=2002\&Freq=Year (accessed July 16, 2004).

Bureau of Labor Statistics, U.S Department of Labor (2004). "Local Area Unemployment Statistics," Bureau of Labor Statistics web site, http://data.bls.gov/servlet/ SurveyOutputServlet (accessed July 14, 2004).

Carasso, Adam, and Eugene Steuerle (2003). "Growth in the Earned Income and Child Tax Credits," Tax Facts column, Tax Notes, 98(3):401.

Clason, George S. (1988). The Richest Man in Babylon. New York: New American Library.

Center on Budget and Policy Priorities (2004). "Facts about the Earned Income Credit," Washington, D.C. http://www.cbpp.org/eic2003/fuctseic-2003.pdf.

Duflo, Esther, William Gale, Jeffrey Liebman, Peter Orszag, and Emmanuel Saez (2005). "Saving Incentives for Low- and Middle-Income Families: Evidence from a Field Experiment with H\&R Block," Retirement Security Project Policy Brief no. 2005-5, May.

Gale, William G., John Sabelhaus, and Robert E. Hall (1999). "Perspectives on the Household Saving Rate," Brookings Papers on Economic Activity, 19(1):181-224.

Haveman, Robert, and Edward Wolff (2001). "Who Are the Asset Poor? Levels, Trends, and Composition, 1983-1998," University of Wisconsin, discussion paper no. 1227-01.

Hubbard, Glen, and Jonathan Skinner (1996). "Assessing the Effectiveness of Saving Incentives," Journal of Economic Perspectives, 10(4):73-90.

Internal Revenue Service, Statistics of Income (2001). "Individual income tax statistics2001, Table 3.3-2001 Individual income tax, all returns: Tax liability, tax credits, tax payments, by size of adjusted gross income," http://www.irs.gov/pub/irs-soi/01in33ar.xls.

Kemmis, Stephen, and Robin McTaggart (1988). The Action Research Planner, Geelong, Victoria: Deakm University Press.

Kiyosaki, Robert T., and Sharon L. Lechter (2000). Rich Dad, Poor Dad: What the Rich Teach Their Kids About Money - That the Poor and Middle Class Do Not! New York: Warner Business Books.

Lee, Andrew, and Robert Greenstein (2003). "How the New Tax Law Alters the Child Tax Credit and How Low-Income Families Are Affected," Washington, D.C.: Center on Budget and Policy Priorities.

Lewin, Gertrude W. (1948). Resolving Social Conflicts: Selected Papers on Group Dynamics. New York: Harper \& Row. 
Page-Adams, Deborah, and Ed Scanlon (2001). "Assets, Health, and Well-Being: Neighborhoods, Families, Children, and Youth," Washington University in St. Louis, research background paper no. CYSAPD 01-9.

Parker, Jonathan (1999). "Spendthrift in America? On Two Decades of Decline in the U.S. Saving Rate," in B. Bernanke and J. Rotemberg (eds.), NBER Macroeconomics Annual 1999, 14(2000):317-370.

Quinn, Jane B. (2001). "Checking Error Could Land You on Blacklist," Washington Post, September 30, 2001, http://global.factiva.com/en/eSrch/ss_hl.asp (accessed March 4, 2004).

Schreiner, Mark, Margaret Clancy, and Michael Sherraden (2002). "Final Report: Saving Performance in the American Dream Demonstration, a National Demonstration of Individual Development Accounts 9," Washington University in St. Louis.

Shefrin, Hersh M., and Richard H. Thaler (1992). "Mental Accounting, Saving, and SelfControl," in G. Loewenstein and J. Elster (eds.), Choice Over Time. New York: Sage Foundation.

Sherraden, Michael (1991). Assets and the Poor: A New American Welfare Policy. Armonk, N.Y.: M.E. Sharpe.

Sherraden, Michael, and Michael Barr (2004). "Institutions and Inclusion in Saving Policy," working paper no. BABC 04-15, http://www.jchs.harvard.edu/publications/ finance/babc/babc_04-15.pdf.

Smeeding, Timothy M., Katherin R. Phillips, and Michael O'Conner (2000). "The Earned Income Tax Credit: Expectation, Knowledge, Use, and Economic and Social Mobility," National Tax Journal, 53(4):1187-1209.

Thaler, Richard H. (1994). "Psychology and Savings Policies," American Economic Review, 84(2):186-192.

Thaler, Richard H. (2000). "From Homo Economicus to Homo Sapiens," Journal of Economic Perspectives, 14(1):133-141.

Thaler, Richard H., and Shlomo Benartzi (2004). "Save More Tomorrow ${ }^{\mathrm{TM}}$ : Using Behavioral Economics to Increase Employee Saving," Journal of Political Economy, 112(1):164187.

Thaler, Richard H., and H. M. Shefrin (1988). "The Behavioral Life-Cycle Hypothesis," Economic Inquiry, 26(4):609-643.

Thompson, Ginger (2002). "Big Mexican Breadwinner: The Migrant Worker," New York Times, 25 March, p. A3.

Tufano, Peter, and Daniel Schneider (2005). "H\&R Block and Everyday Financial Services, HBS Case No. 205-013." Boston, Mass.: Harvard Business School Publishing.

Tufano, Peter, and Daniel Schneider (2005). "Reinventing Savings Bonds." Special Report, Tax Notes, 109(5):637-656.

U.S. Census Bureau (2000). "Census 2000 Population, Demographic, and Housing Information, Tulsa, Oklahoma," http://quickfacts.census.gov/qfd/states/40/40143lk.html (accessed September 30, 2004). 
Caner, Asena, and Edward Wolff (2002). "Asset Poverty in the United States, 1984-1999: Evidence from the Panel Survey of Income Dynamics." Working paper no. 356. N.Y.: Levy Economics Institute, Annandale-on-Hudson.

Wolff, Edward, and Asena Caner (2004). "Asset Poverty in the United States, Its Persistence in an Expansionary Economy," public policy brief 76. Annandale-on-Hudson, N.Y.: Levy Economics Institute.

Woo, Lillian, F., William Schweke, and David E. Buchholz (2004). "Hidden in Plain Sight: A Look at the $\$ 335$ Billion Federal Asset-Building Budget." Washington, D.C.: Corporation for Enterprise Development. 